\title{
7. SITE 518: WEST FLANK, RIO GRANDE RISE ${ }^{1}$
}

\author{
Shipboard Scientific Party ${ }^{2}$
}

\section{HOLE 518}

\begin{abstract}
Date occupied: 3 April 1980
\end{abstract}
Date departed: 4 April 1980

Time on hole: $35.5 \mathrm{hr}$.

Position: $29^{\circ} 58.42^{\prime} \mathrm{S}, 38^{\circ} 08.12^{\prime} \mathrm{W}$

Water depth (sea level; corrected m, echo-sounding): 3944

Water depth (rig floor; corrected m, echo-sounding): 3954

Bottom felt (m, drill pipe): 3946.0

Penetration (m): 76.7

Number of cores: 19

Total length of cored section $(\mathrm{m}): \mathbf{7 6 . 7}$

Total core recovered $(\mathrm{m}): 59.57$

Core recovery $(\%): 78$

Oldest sediment cored:

Depth sub-bottom (m): 72.3

Nature: Marly calcareous ooze

Age: early Miocene (18 to $19 \mathrm{Ma}$ )

Measured velocity $(\mathrm{km} / \mathrm{s}): 1.5$

Principal results: Site 518 was cored by the hydraulic piston corer (HPC) in the sediments beneath Antarctic Bottom Water/North Atlantic Deep Water (AABW/NADW) transition zone on the east flank of the Vema Channel. Paleontologic, lithologic, and geochemical analyses at this site reflect the history of deep thermohaline flow during the Neogene.

The terminal Miocene (5.4-6.0 Ma) is marked by heavy values of $\delta^{13} \mathrm{C}$, minimal carbonate dissolution, and the presence of a benthic foraminiferal assemblage (Uvigerina peregrina-Globocassidulina subglobosa) indicating a young, well-oxygenated Circumpolar Water (CPW) that expanded northward to the latitude of the Rio Grande Rise. The data suggest that there was no production of either NADW or AABW during the Messinian.

An erosional unconformity spans the Miocene/Pliocene boundary and the lowest Pliocene (about 4.0-5.4 m.y. in age). Directly above the unconformity, benthic foraminifers characteristic of both AABW (Nuttalides umbonifera) and NADW (Oridorsalis umbonatus-Epistominella exigua) reappear in lower Pliocene sediments (3.6-4.0 Ma). Concurrently, the $\delta^{13} \mathrm{C}$ gradient in benthic

\footnotetext{
${ }^{1}$ Barker, P. F., Carlson, R. L., Johnson, D. A., et al., Init. Repts. DSDP, 72: Washing. ton (U.S. Govt. Printing Office).

2 Peter F. Barker (Co-Chief Scientist), Department of Geological Sciences, University of Birmingham, Birmingham, United Kingdom; Richard L. Carlson (Co-Chief Scientist), Department of Geophysics, Texas A\&M University, College Station, Texas; David A. Johnson (Co-Chief Scientist), Department of Geology and Geophysics, Woods Hole Oceanographic Institution, Woods Hole, Massachusetts; Pavel Ćepek, Bundesanstalt für Geowissenschaften und Rohstoffe, Hannover, Federal Republic of Germany; William T. Coulbourn, Deep Sea Drilling Project, Scripps Institution of Oceanography, La Jolla, California; Luiz A. Gamboa, Lamont-Doherty Geological Observatory, Palisades, New York, (present address: Center for Marine Crustal Studies, Gulf Science and Technology, Pearl River, New York); Norman Hamilton, Department of Geology, University of Southhampton, Southhampton, United Kingdom; Ubirajara de Melo, PETROBRAS, Centro de Pesquisas e Desenvolvime

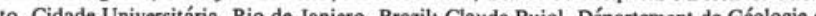
o, Cidade Universitária, Rio de Janiero, Brazil, Claude Pujol, Département de Geologie et Océanographic, Université de Bordeaux, 33405 Talence, France; Alexander N. Shor, LamontDoherty Geological Observatory, Palisades, New York; Alexey E. Suzyumov, P. P. Shirshov Institute of Oceanology, U.S.S.R. Academy of Sciences, Moscow, U.S.S.R.; R. C. Tjalsma Exploration and Production Research Laboratory, Cities Service Company, Tulsa, Oklahoma; William H. Walton, Department of Civil Engineering, Cornell University, Ithaca, New York (present address: Charles T. Main, Inc., Boston, Massachusetts).
}

foraminifers increases between Sites 516 and 518, and dissolution increases. These faunal, isotopic, and lithologic changes reflect the displacement of circumpolar waters by the reinitiation of both NADW and AABW flow. Between 3.6 and 3.2 Ma, the production of both NADW and AABW diminished, and a youthful CPW expanded northward to the latitude of the Rio Grande Rise. This event corresponds to an intensification in the Antarctic Circumpolar Current about 3.4 Ma (Ciesielski et al., 1982). During the middle Pliocene (about 2.7-3.2 Ma) at Site 518, the AABW and NADW benthic assemblages reappear, carbonate dissolution increases, and the vertical gradient of $\delta^{13} \mathrm{C}$ in benthic foraminifers on the Rio Grande Rise increases sharply. These changes imply a marked intensification of both NADW and AABW flow; they are coincident with the benthic enrichments in $\delta^{18} \mathrm{O}$ at Sites 516 and 518 and with the inferred initiation of ice growth in the northern hemisphere at $3.2 \mathrm{Ma}$.

A noteworthy aspect of the Site 518 data is that, during the Pliocene, intensifications of AABW and NADW were apparently synchronous. If this timing is verified upon further study, it will support the notion that the advection of high-salinity water from the North Atlantic (NADW) may be a necessary precondition to the formation of bottom water in high southern latitudes (AABW).

\section{BACKGROUND AND OBJECTIVES}

Site 518 is located in a water depth of $3944 \mathrm{~m}$ on the lower west flank of the Rio Grande Rise (Fig. 1), within the transition zone between Antarctic Bottom Water (AABW) and North Atlantic Deep Water (NADW). Previous hydrographic surveys in the Vema Channel region (Johnson et al., 1976; Hogg et al., 1982) have documented that a sharp benthic thermocline intersects the seafloor between 4000 and $4200 \mathrm{~m}$ on the east flank of the channel. Geologic investigations of closely spaced cores (Johnson et al., 1977; Lohmann, 1978; Ledbetter, 1979) show steep gradients in the lithologic and paleontologic components of the surface sediment within this transitional zone. The geologic record may, therefore, be interpreted in terms of vertical fluctuations of this zone during the late Cenozoic. Stratigraphic sections at Sites 515 and 518 record the timing of the major pulses of AABW flow during the Cenozoic.

Piston and gravity cores on the east flank of the Vema Channel show that reliable paleomagnetic and biostratigraphic control is present in cores shallower than approximately $4000 \mathrm{~m}$ (Johnson et al., 1977). At greater water depth, calcareous microfossils disappear, and the dominant sediment type is a nonfossiliferous zeolitic clay with manganese micronodules and pavements (Williams and Ledbetter, 1979). Stratigraphic control is essential in order to reliably interpret fluctuations of deep water masses. Consequently, Site 518 was positioned at the approximate depth of Core CHN 115-92, where an excellent upper Pleistocene record of carbonate fluctuations, oxygen isotope stratigraphy, benthic foraminiferal populations, displaced Antarctic diatoms, and grain- 


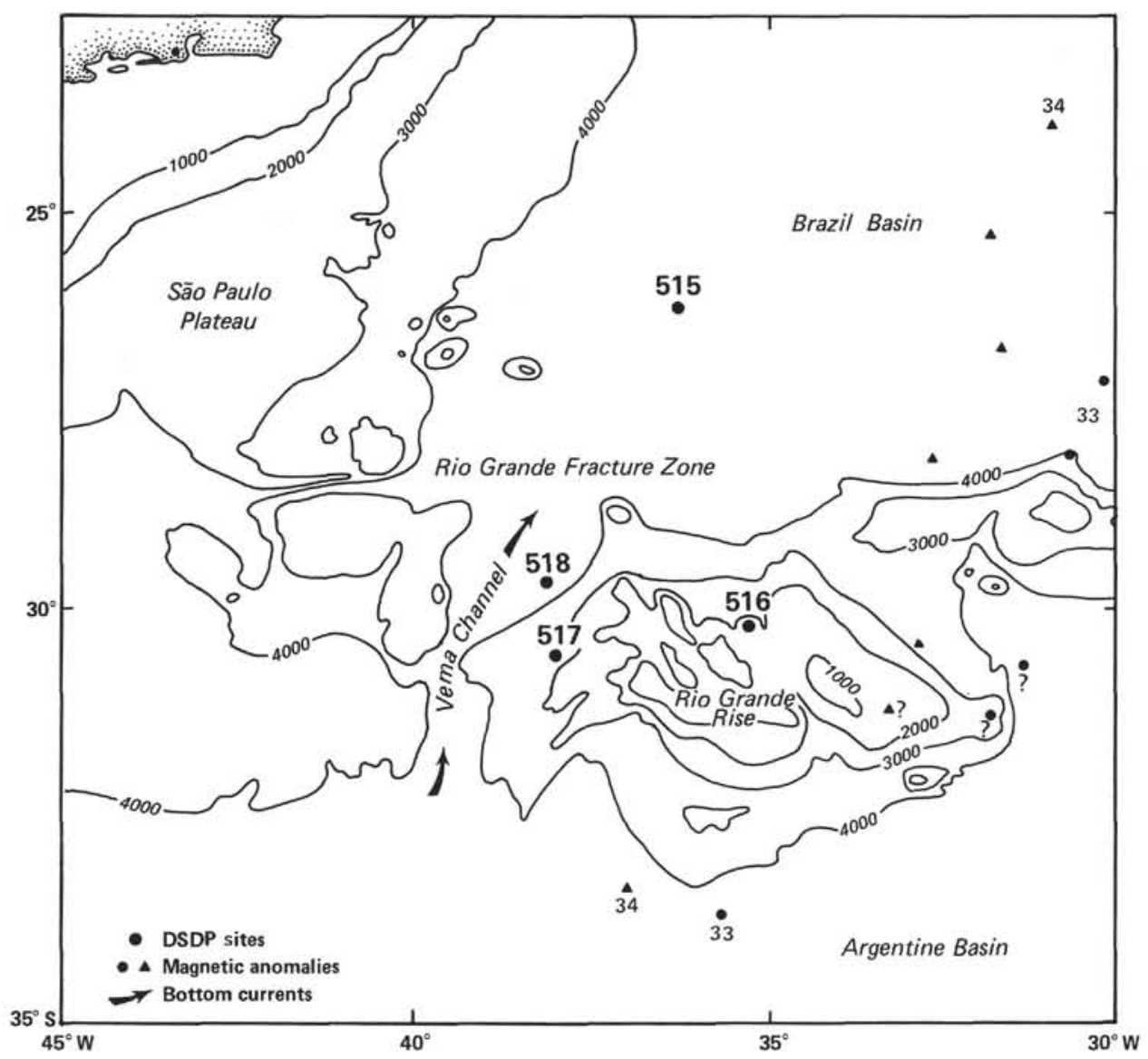

Figure 1. Location map showing positions of Leg 72 sites, marine magnetic anomalies, and generalized bathymetry.

size parameters have already been obtained (Johnson et al., 1977; Ellwood and Ledbetter, 1977; Lohmann, 1978; Ledbetter, 1979). We intended to extend these interpretations as far back into the Neogene as stratigraphic control at Site 518 would allow.

In view of the little time that remained for drilling and coring on Leg 72 , Site 518 was cored with HPC to refusal. Because adverse weather conditions forced premature abandonment of Site 517, it was even more critical that Site 518 be cored as completely as possible in order to extend back into the Neogene the paleoceanographic interpretations already proposed for the late Pleistocene on the basis of the CHN-115 cores (Johnson et al., 1977).

The following are among the principal questions addressed in analyses of samples from Site 518:

1) Do the maxima in AABW transport, as recorded at Site 515 in the Brazil Basin, correspond to a shallowing of the AABW/NADW transition zone in the Vema Channel? What are the relationships between AABW flux into the Brazil Basin, and AABW thickening within the Vema Channel proper? How are these fluctuations related to the glacial/interglacial chronology of the late Pleistocene?

2) What was the effect of the initiation of northern hemisphere glaciation in the Pliocene upon the AABW/ NADW transition?
3) What are the phase relationships between AABW production and NADW production during the late Pleistocene? How does the AABW/NADW transition zone move in response to these two forcing functions?

\section{OPERATIONS}

After abandoning Site 517 because of adverse weather, we arrived in the vicinity of Site 518 on the morning of 1 April in a fresh southeasterly gale that prevented us from occupying the site. In anticipation of moderating conditions, we dropped a beacon at $1012 \mathrm{Z}$ on 1 April, which we then used as a reference point while we profiled within a 40 -mile radius.

At 1006Z, 2 April, we retrieved profiling gear as we approached the area of the beacon in moderating weather. By 1530Z, 2 April, we had occupied Site 518 at $29^{\circ} 58.42^{\prime} \mathrm{S}, 38^{\circ} 08.12^{\prime} \mathrm{W}$ in $3946 \mathrm{~m}$ of water. The hole was spudded at $0200 \mathrm{Z}$ on 3 April, and we began continuous coring with the HPC. By $0300 \mathrm{Z}$ on 4 April, we had recovered middle Miocene sediments, our objective for the site (Table 1).

\section{SEDIMENT LITHOLOGY}

Site 518 is a single HPC hole. The deepest sediment recovered came from $71.94 \mathrm{~m}$ sub-bottom in Core 18 (Core 19 was empty). The sediment is divided into two lithologic units (Fig. 2): 
Table 1. Coring summary, Site 518.

\begin{tabular}{|c|c|c|c|c|c|c|c|}
\hline Core & $\begin{array}{l}\text { Date } \\
\text { (April } \\
1980 \text { ) }\end{array}$ & $\begin{array}{c}\text { Time } \\
\text { (Z) }\end{array}$ & $\begin{array}{l}\text { Depth from } \\
\text { drill floor } \\
\text { (m) }\end{array}$ & $\begin{array}{l}\text { Depth below } \\
\text { seafloor } \\
\text { (m) }\end{array}$ & $\begin{array}{l}\text { Length } \\
\text { cored } \\
\text { (m) }\end{array}$ & $\begin{array}{l}\text { Length } \\
\text { recovered } \\
\text { (m) }\end{array}$ & $\begin{array}{c}\text { Core } \\
\text { recovered } \\
(\%)\end{array}$ \\
\hline 1 & 3 & 0231 & $3946.0-3946.9$ & $0.0-0.9$ & 0.9 & 0.85 & 94 \\
\hline 2 & 3 & 0356 & $3946.9-3951.3$ & $0.9-5.3$ & 4.4 & 4.54 & $100+$ \\
\hline 3 & 3 & 0548 & $3951.3-3955.7$ & $5.3-9.7$ & 4.4 & 4.48 & $100+$ \\
\hline 4 & 3 & 0700 & $3955.7-3960.1$ & $9.7-14.1$ & 4.4 & 4.26 & 97 \\
\hline 5 & 3 & 0828 & $3960.1-3964.5$ & $14.1-18.5$ & 4.4 & 4.13 & 94 \\
\hline 6 & 3 & 0940 & $3964.5-3968.9$ & $18.5-22.9$ & 4.4 & 4.52 & $100+$ \\
\hline 7 & 3 & 1045 & $3968.9-3973.3$ & $22.9-27.3$ & 4.4 & 3.77 & 86 \\
\hline 8 & 3 & 1147 & $3973.3-3977.7$ & $27.3-31.7$ & 4.4 & 4.61 & $100+$ \\
\hline 9 & 3 & 1300 & $3977.7-3982.1$ & $31.7-36.1$ & 4.4 & 3.36 & 76 \\
\hline 10 & 3 & 1404 & $3982.1-3986.5$ & $36.1-40.5$ & 4.4 & 2.83 & 64 \\
\hline 11 & 3 & 1628 & $3986.5-3990.9$ & $40.5-44.9$ & 4.4 & 3.70 & 84 \\
\hline 12 & 3 & 1731 & $3990.9-3995.3$ & $44.9-49.3$ & 4.4 & 1.40 & 32 \\
\hline 13 & 3 & 1839 & $3995.3-3999.7$ & $49.3-53.7$ & 4.4 & 1.80 & 41 \\
\hline 14 & 3 & 2008 & $3999.7-4000.7$ & $53.7-54.7$ & 1.0 & 0.35 & 35 \\
\hline 15 & 3 & 2136 & $4000.7-4005.1$ & $54.7-59.1$ & 4.4 & 4.64 & $100+$ \\
\hline 16 & 3 & 2252 & $4005.1-4009.5$ & $59.1-63.5$ & 4.4 & 2.91 & 66 \\
\hline 17 & 4 & 0011 & $4009.5-4013.9$ & $63.5-67.9$ & 4.4 & 3.38 & 77 \\
\hline 18 & 4 & 0130 & $4013.9-4018.3$ & $67.9-72.3$ & 4.4 & 4.04 & 92 \\
\hline \multirow[t]{2}{*}{19} & 4 & 0259 & $4018.3-4022.7$ & $72.3-76.7$ & 4.4 & 0.00 & 0 \\
\hline & & & & & 76.7 & 59.57 & 78 \\
\hline
\end{tabular}

\section{Unit 1: Calcareous Oozes (0-54.7 m sub-bottom)}

Unit 1 spans Cores 1 to 14 and contains Quaternary to upper Miocene calcareous oozes. Core 518-1 to Sample $518-5-2,76 \mathrm{~cm}$ are foraminiferal-nannofossil ooze, varying in color from light olive gray in Core 1 to very pale brown in Cores 2 to 5 . Three foraminiferal sand layers from 32 to $87 \mathrm{~cm}$ in thickness occur within Cores 3 and 5. These are probably turbidites, although no grading was observed. Nannofossil ooze is the dominant lithology from Core 5 to Sample 518-8-2, $108 \mathrm{~cm}$, with interbedded very pale brown ooze as above. Sediments from Cores 8 to 14 are dominantly foraminiferal-nannofossil oozes, varying from light yellowish brown to white.

Cores 1 to 7 are Quaternary; 8 to 11 are Pliocene; and 12 to 14 are upper Miocene. Evidence for hiatuses between Cores 7 and 8,11 and 12 , and 14 and 15 is fairly

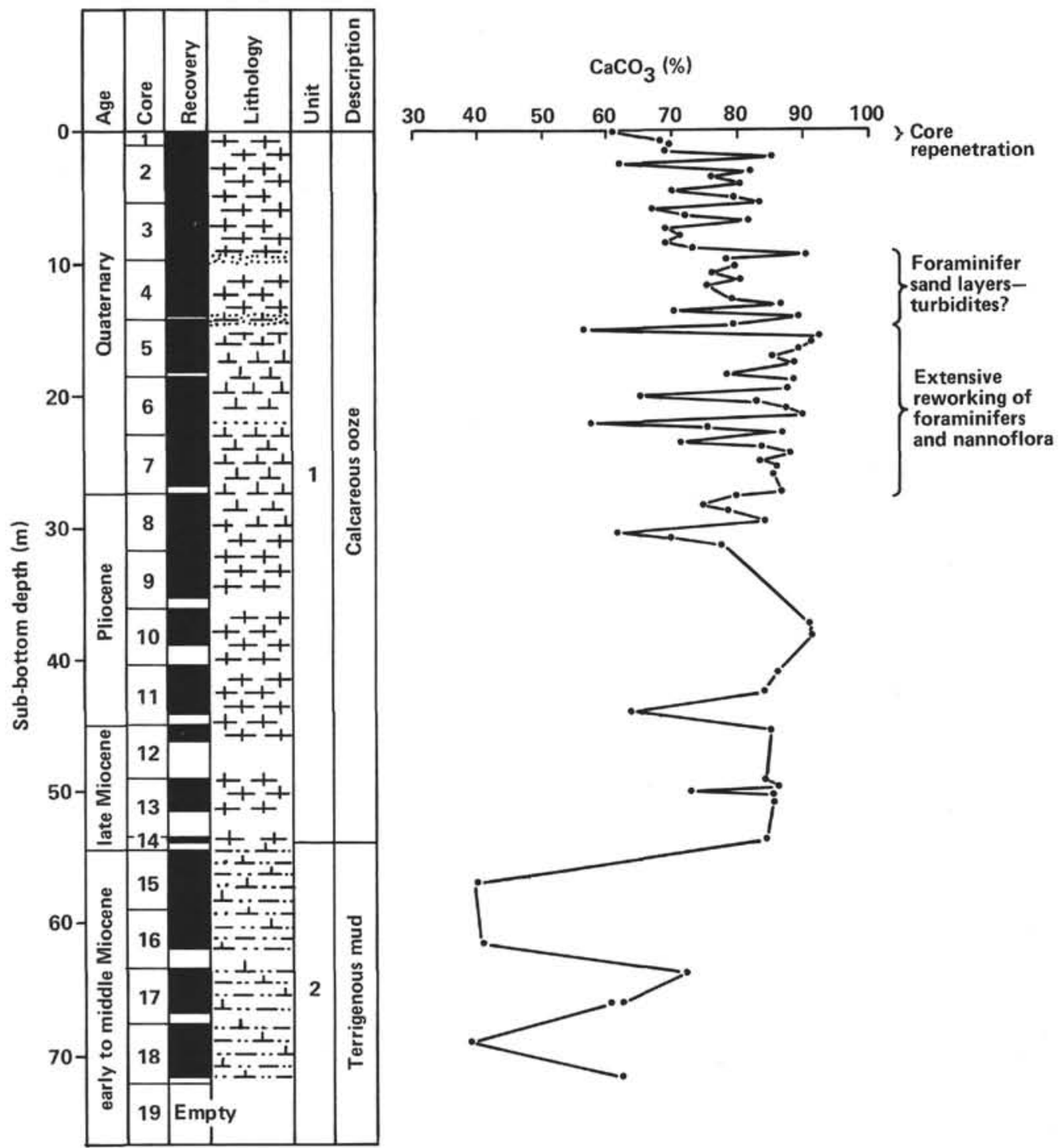

Figure 2. Sediment lithology summary and percent carbonate, Site 518. Symbols according to DSDP convention (Coulbourn, this volume). 
good. Nannofossils and foraminifers are extensively reworked in the lower Quaternary of Cores 5 to 7. In these cores, the Pliocene rather than the Pleistocene sediments are more extensively reworked.

Sedimentary structures are rare in Unit 1 . The only primary structures, aside from a few faint parallel laminations, are the foraminiferal sand layers described above. Burrow mottling is not common; its apparent absence is perhaps partly a result of the subtle color differences within the unit, making mottling difficult to detect.

Carbonate bomb analyses from Unit 1 are summarized in Figure 2, and values are tabulated on this chapter's core description forms. Most analyses range between 65 and $90 \%$. Four of the highest values $(89-92 \%)$ are from foraminiferal sand layers.

Induration increases between Cores 8 and 9, and HPC penetration dropped to only about $3 \mathrm{~m}$ per core; it dropped again to less than $2 \mathrm{~m}$ in Cores 11 and 12 .

Sediment composition in Cores 1 to 9 of Unit 1 includes $60-80 \%$ nannofossils, $0-20 \%$ foraminifers, $10-40 \%$ clay, $1-3 \%$ limonitic aggregates (iron oxide clay aggregates), and trace to $1 \%$ of volcanic glass, micronodules, quartz, feldspar, and heavy minerals. Noncarbonate sand and silt increase in Cores 10 to 14, with approximately $10 \%$ of the clay noted above replaced by quartz and feldspar $(3 \%)$, volcanic glass $(5 \%)$, and scattered glauconite ( 2 to $4 \%$ ). Zeolite occurs in Sample $518-11-1,70 \mathrm{~cm}$.

\section{Unit 2: Terrigenous Muds and Marly Nannofossil Oozes (54.7-71.9 m sub-bottom)}

Unit 2 spans Cores 15 to 18 and consists of middle Miocene terrigenous muds (Core 15 only) and marly nannofossil oozes. Colors vary within Unit 2 more than within the overlying unit, ranging from dark reddish gray (muds) to pale brown, light reddish brown and yellowish brown (marly oozes).

This unit is moderately burrowed (where not too deformed by coring) and more laminated than the overlying unit. Sand layers and cross-laminated intervals are absent.

The terrigenous mud in Core 15 contains zeolites (about 10\%), in addition to $20 \%$ quartz and feldspar, $10 \%$ volcanic glass, $5 \%$ heavy minerals, $5 \%$ nannofossils, and $50 \%$ clay (smear slide estimate). The marly oozes in this unit contain $40-60 \%$ nannofossils, $0-10 \%$ foraminifers, $5-10 \%$ terrigenous mineral grains (quartz, feldspar, heavy minerals), 1-10\% volcanic glass, and scattered glauconite and zeolites (1-5\% each). Claysized noncarbonate sediment makes up the remaining $30-50 \%$.

Unit 2 is middle to early Miocene in age and is terminated by either an unconformity or a mud unit that accumulated extremely slowly (upper $2.5 \mathrm{~m}$ of Core 15 ).

\section{SEDIMENTARY GEOCHEMISTRY}

\section{Carbonate Analysis}

Eighty carbonate analyses were completed for Hole 518 (Fig. 2).

\section{X-Ray Diffraction Analysis}

X-ray diffractograms for 30 samples from Hole 518 register peaks for calcite. Lower amplitude peaks suggest that quartz is also present throughout the section. Illite occurs in most intervals sampled and dominates the diffraction pattern for a specimen from Sample 518$15-1,104 \mathrm{~cm}$, sediment deposited in a time of intense dissolution relative to the other intervals that were recovered at Site 518 .

\section{BIOSTRATIGRAPHY}

The lithology of the 19 cores from Site 518 ranges from nannofossil-foraminiferal ooze at the top to terrigenous muds in the lower intervals. The oldest sediment recovered was early Miocene (Zones NN4/5 and N6; approximately 18-19 Ma).

\section{Stratigraphic Continuity}

Four stratigraphic gaps occur within the sequence cored at Site 518. From top to bottom, they are as follows:

1) There may be a gap of about $1 \mathrm{Ma}$ in the upper Pliocene/lower Pleistocene. Planktonic foraminiferal Zones PL5 and PL6 and nannofossil Zones NN17/18 are absent. Pliocene sediment is reworked into the Quaternary of Cores 5 through 7.

2) A gap of at least $1 \mathrm{Ma}$ occurs in the lower Pliocene/upper Miocene. Planktonic foraminiferal Zones PL1a and PL1b and nannofossil Zones NN12 and NN13 are probably missing.

3) The upper Miocene may be largely missing, as was true at Site 516. The interval including the top of Zone NN9, Zone NN10, and most of Zone NN11 was not found, corresponding to an age of approximately 6-11 Ma.

4) A gap of at least 2 Ma may be present in the middle Miocene. The interval that is apparently missing includes part of Zone NN5, all of NN6, and most of NN7.

\section{Microfossil Abundance and Preservation}

Planktonic foraminifers are sufficiently abundant and well preserved in most of the cores at Site 518 to allow recognition of most of the stratigraphically diagnostic taxa. Preservation is notably poor in the middle Miocene (Cores 15 through 17), but elsewhere is generally good.

Calcareous nannoplankton are abundant throughout the cored interval. Preservation is moderate to good in the Quaternary, moderate in the Pliocene-upper Miocene, and poor to moderate in the lower and middle Miocene. Fragmentation occurs throughout, and dissolution persists down through the middle Miocene (Core 16). Calcite overgrowths are common on discoasters throughout the Miocene. Taxa of Helicopontosphaera are dissolved in Cores 16 to 18, preventing discrimination between Zones NN4 and NN5.

Benthic foraminifers are generally low in abundance, but increase in abundance below Core 15 where dissolution of the less-resistant planktonic components be- 
comes significant. Preservation ranges from good to poor and decreases downward in the section.

\section{Reworking}

Pliocene planktonic foraminifers and nannoplankton are the dominant constituents in extensively reworked Quaternary sediments (Cores 5 through 7). Middle Miocene planktonic foraminifers are reworked into the upper Miocene sediments of Core 12. Nannoplankton show a small degree of reworking in virtually every core, most significantly in Cores 5 to 7 .

Benthic foraminifers show no evidence for the downslope reworking from shallower depths on the Rise, but the benthics in Cores 15 to 17 are quite large, suggesting that these cores may constitute a lag deposit or dissolution facies.

\section{Nannoplankton}

Calcareous nannoplankton were identified in each of the 18 cores from Site 518. The nannofossils are abundant, but preservation fluctuated from poor to good because of dissolution, fragmentation, and overgrowth. The same biozonation for the Tertiary was used as was used for Sites 515, 516, and 517 (see Berggren, Aubry, and Hamilton, this volume). Twenty samples were investigated for biostratigraphic age determination of Tertiary sediments, and nine calcareous nannoplankton zones representing four biostratigraphic intervals were identified:

1) Quaternary (518-1,CC to $518-7, \mathrm{CC} ; 0-27.3 \mathrm{~m})$

2) Pliocene (518-8,CC to $518-11, \mathrm{CC} ; 31.7-44.9 \mathrm{~m})$

3) upper Miocene $(518-12, \mathrm{CC}$ to $518-14, \mathrm{CC}$; 49.3$54.7 \mathrm{~m}$ )

4) lower to middle Miocene (518-15,CC to 518-18, CC; 63.5-72.3 m)

\section{Quaternary}

Abundant and moderately to well-preserved Quaternary calcareous nannoplankton occur in the interval between Samples 518-1,CC and 518-7,CC. Dissolution, reworking, and fragmentation characterize all samples. The assemblages in Core 518-1 to Sample 518-2-1, 60-61 $\mathrm{cm}$ belong to Zones NN21 and NN20. The last occurrence of Pseudoemiliania lacunosa in Sample 518-2-2, $60-61 \mathrm{~cm}$ defines the base of Zone NN20 and the top of Zone NN19. The base of Zone NN19 occurs in Sample 518-7,CC. From the top of the core to Sample 4,CC, $P$. lacunosa is present without any discoasters. The lower part of this interval, extending to the base of Core 7, is represented by assemblages that are a mixture of coccoliths from the $P$. lacunosa Zone and calcareous nannoplankton of the upper Pliocene (Zones NN16 to NN18). But this assemblage belongs to Zone NN19, because the Quaternary species of nannofossils, like $\mathrm{Ge}$ phyrocapsa oceanica (its range is NN19 to NN21) and Ceratolithus cristatus (its range is the upper part of NN18 to NN21) are present.

\section{Pliocene}

The Pliocene assemblages are abundant with moderate preservation. The assemblage of Sample 518-8,CC contains Discoaster surculus but lacks Reticulofenestra pseudoumbilica, indicating Zone NN16. There is no evidence of younger index fossils in this core. The co-occurrence of $R$. pseudoumbilica and $D$. asymmetricus in Sample 518-9, CC indicates an age corresponding to Zones NN14 to NN15. Amaurolithus tricorniculatus and A. delicatus were not observed, preventing a more precise age determination. In Samples 518-10,CC and 518$11, C C$, the overlapping ranges of $D$. asymmetricus and $A$. delicatus indicate Zone NN14. There is no evidence for Zones NN13 and NN12 at this site, suggesting an unconformity of about $1.5 \mathrm{Ma}$.

\section{Upper Miocene}

The upper Miocene interval is very short, but it contains abundant and moderately preserved calcareous nannofossils. The co-occurrence of $A$. delicatus and $D$. quinqueramus indicate that Sample $518-12, \mathrm{CC}$ to $\mathrm{Sec}-$ tion 518-14-1 belong to the top of Zone NN11. According to Haq and Berggren (1978), this interval belongs to the $A$. delicatus Zone, which covers the base of Martini's (1971) NN12 Zone and the top of NN11 Zone. Between Zone NN11 and the next interval (top of NN7 to base of NN9), there is probably a hiatus of about $5 \mathrm{Ma}$.

\section{Middle to Lower Miocene}

Coccoliths and discoasters recovered in middle Miocene Sample $518-15, \mathrm{CC}$ are abundant but poorly preserved. Age assignment for this sample is difficult because no index fossils were recognized, probably a result of poor preservation. The age is no younger than the base of Zone NN9 (based on the absence of $D$. pentaradiatus), and no older than the top of NN7 (based on the presence of $D$. challengeri).

Another hiatus of about 1 Ma may be present between this and the next underlying interval. The interval between Samples 518-16,CC and 518-18,CC contains abundant and moderately preserved calcareous nannoplankton with Sphenolithus heteromorphus but without $S$. belemnos, thereby assigning this interval to Zones NN4 to NN5. Helicopontosphaera intermedia was not recognized, which should limit this interval to Zone NN5. Other species of Helicontosphaera are not present, however, suggesting that this genus is largely dissolved, thereby making discrimination between Zones NN4 and NN5 difficult.

\section{Planktonic Foraminifers}

The hole drilled at Site 518 cut through a sequence extending from the Recent to the lower Miocene with perhaps one unconformity at the upper middle and lower upper Miocene. Berggren's (1977a, b) zonation is used for the Pliocene and Blow's (1969) for the Miocene. Planktonic foraminifers are abundant, but dissolution fluctuated from slight to important. Four biostratigraphic intervals were identified:

1) Quaternary (Core 518-1 to Section 518-5-3)

2) Pliocene (Sample 518-5, CC to Section 518-11-1)

3) upper Miocene (Section 518-11-2 to Sample 518$14, \mathrm{CC})$ 
4) lower to middle Miocene (Section 518-15-1 to Sample 518-18,CC)

\section{Quaternary}

A good Quaternary sequence was retrieved in Cores 1 to 7, and Zone N23 is identified from the presence of Globorotalia hirsuta. Below this zone, the presence of $G$. truncatulinoides and a subtropical to transitional assemblage indicate that the sequence is Pleistocene (Zone N22).

\section{Pliocene}

Pliocene sediments were recovered in Cores 6 to 11 . The assemblage is mixed with a Pleistocene association in Cores 6 and 7 and in the core catcher of Core 5; therefore, the differentiation of the PL6 Zone of Berggren $(1977 \mathrm{a}, \mathrm{b})$ is difficult. Zone PL6 is, nevertheless, present in Core 6, Sections 1 and 2, with G. exilis/pertenuis and without $G$. miocenica. Zone PL5 occurs between Sample 518-8,CC, the last occurrence of Globoquadrina altispira, and Section 518-6-3, the last occurrence of Globorotalia miocenica. The core catcher of Core 8 contains Globoquadrina altispira but no Sphaeroidinellopsis sp. and accordingly belongs to Zone P14. Zone PL3 occurs in Section 518-9-1. Zone PL2 is present from Sections 518-9-2 to 518-10-2, and Zone PL1 occurs between Sample 518-10,CC and Section 518-11-1. The last occurrence of Globoquadrina dehiscens marks the base of the Pliocene.

\section{Upper Miocene}

The association of G. dehiscens and Globorotalia margaritae between Sections 518-11-2 and 518-13-1 is typical of the Globorotalia margaritae-Globoquadrina dehiscens Zone and corresponds with the top of the upper Miocene (Zone N17). Below this level, samples in Cores 13 and 14 contain an association of species also belonging to the upper Miocene, but components of Pleistocene to Pliocene assemblages are present as contaminants.

\section{Lower to Middle Miocene}

Contamination of the Pleistocene and Pliocene assemblage is extensive in Cores 15 and 16. Additionally, the dissolution of these samples is very high; some of them are barren. Core 17 contains few specimens of Praeorbulina transitoria, Globorotalia zealandica, G. praemenardii, and $G$. miozea. This association indicates that this interval may be assigned to the base of Zone N9.

The assemblage of Core 18 is poor and largely dissolved. A few specimens of resistant species like Sphaeroidinellopsis seminulina, G. miozea, Globoquadrina dehiscens, and perhaps Globorotalia praescitula suggest that this sequence is lower Miocene, probably the upper part.

\section{Benthic Foraminifers}

Benthic foraminifers are generally low in abundance at Site 518. The assemblages are homogeneous without indications for downslope faunal contamination. The presence of large Stilostomella in Cores 15 to 17 is an indication of a lag deposit, as S. aculeata, at least in the Oligocene, has its optimal abundance below $3 \mathrm{~km}$. These occurrences seem related to the unconformity between the base of Cores 14 and 15 , and possibly to stratigraphic gaps or intervals of unusually low sedimentation rates in Cores 15 to 17 .

As in the previous sites, a core-top sample was studied, although mechanical problems at Site 518 make this core top less reliable. In the greater-than-250-micron fraction the benthic assemblage is dominated by Nuttallides umbonifera $(30 \%)$, with lower percentages of Planulina wuellerstorfi (16\%), Pyrgo spp. (12\%), Oridorsalis umbonatus $(9 \%)$, and $O$. tener $(9 \%)$. This distribution corresponds to that of Lohmann (1978) who records $N$. umbonifera abundances of 26 and $29 \%$, respectively, from the tops of Vema Channel piston and gravity Cores CHN 115-92 (3934 m).

Because Site 518 is located in the transition zone between NADW and AABW, fluctuations in the relative strength of the two flows should produce vertical migrations of this transition zone. In order to test this concept, a quick survey of core catcher samples was made, using counts for the greater-than-149-micron fraction. In those samples, the abundance of $N$. umbonifera remains relatively constant in Cores 1 through 3 (Zone $\mathrm{N} 23$ and part of N22), but increases substantially in Core 4. No counts were made in Cores 5 and 6 because of the mixed nature of the fauna and flora (Pliocene admixed into Quaternary). Sample 518-7,CC again shows a higher than average $(30 \%)$ abundance of $N$. umbonifera. During the time interval covered by Cores 5,6 , and part of 7, Site 518 was apparently within the AABW regime entirely, and the transition zone between the two water masses was shallower than today.

The abundance of $N$. umbonifera decreases drastically in Cores 8 and 9, coinciding with markedly improved preservation of the foraminiferal faunas. In Cores 10 and 11 , the frequencies of $N$. umbonifera equal those of Cores 1 through 3. The fluctuations in abundance of $N$. umbonifera and in preservation of planktonic foraminifers suggest that during the middle Pliocene (Zones PL2 to PL4) the transition zone moved downslope and left Site 518 entirely under the influence of less corrosive NADW, and that during the early Pliocene (PL1c), the transition zone corresponded approximately with the depth of Site 518, as was the case during the late Quaternary. Compare the benthic foraminiferal data with that for the Quaternary of Site 517 at $2923 \mathrm{~m}$ water depth (Fig. 3). The dominant species is Globocassidulina subglobosa, one of several species characteristic of NADW. During the late Pliocene (PL3-5), N. umbonifera became dominant, with frequencies between 22 and $42 \%$. This dominance reversal could mean that during the late Pliocene AABW extended upslope as far as Site 517.

$N$. umbonifera is much less abundant in the Miocene of Site 518. Species diversity of the assemblages is generally higher, in particular in Cores 12 to 13 where preservation is relatively good. Species dominance is generally lower, and the general appearance of the assemblages differs by the addition of characteristic Mio- 

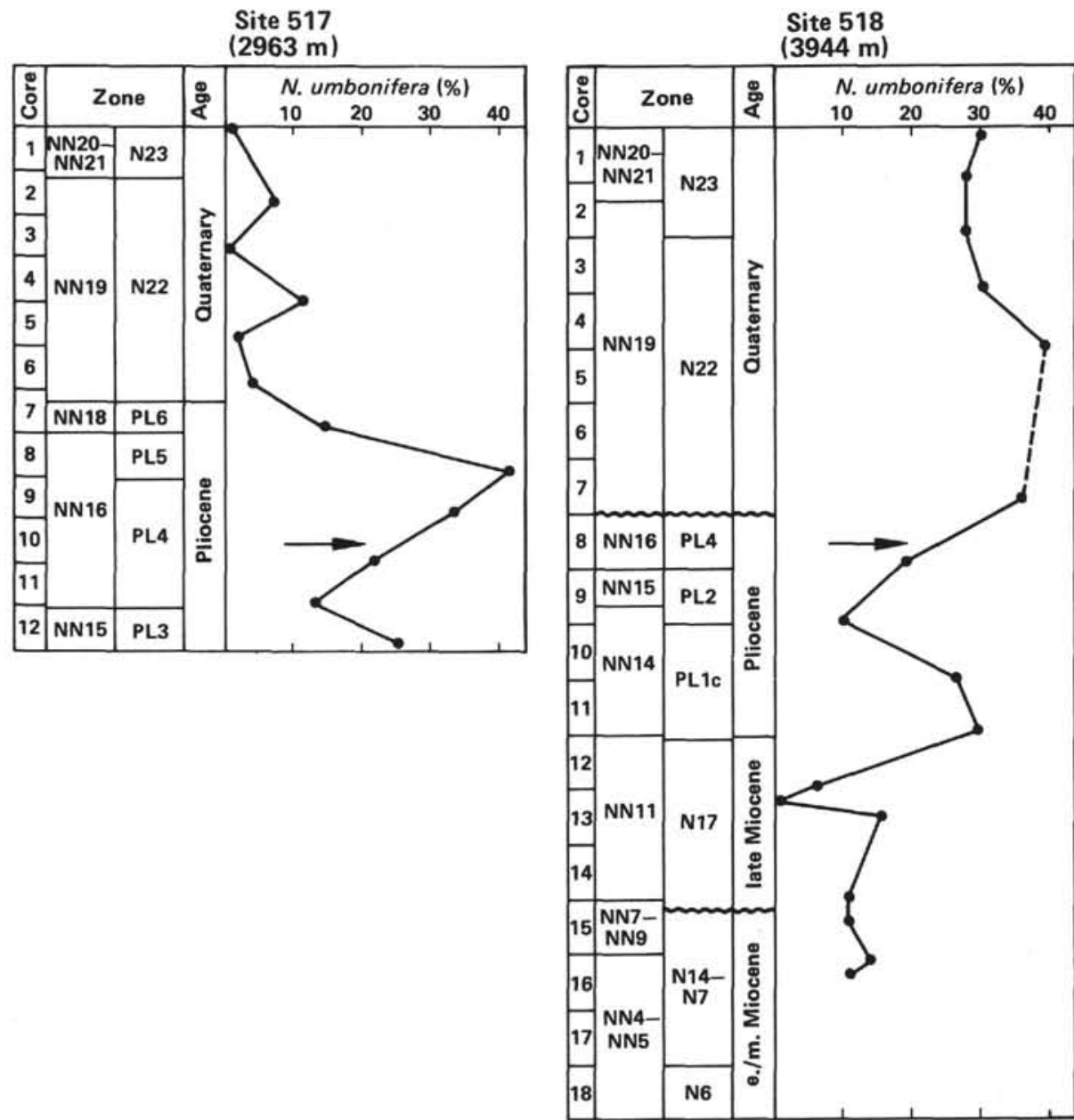

Figure 3. Frequency distribution of the AABW indicator species Nuttalides umbonifera $(>150 \mu \mathrm{m}$ fraction) in the cored section of Sites 517 and 518. Arrow designates a sharp increase in abundance during the middle Pliocene, perhaps indicating a shallowing or intensification of AABW flow.

cene (and Oligocene) species, such as Stilostomella aculeata, $S$. subspinosa, Buliminella grata, B. impendens, Cibicidoides ungerianus, $C$. robertsonianus, and Gavelinella semicribrata.

If the association between Nuttalides umbonifera and AABW can be extended down to the Miocene, then during the late and middle Miocene, Site 518 was fully within the regime of NADW. Furthermore, the good correlation between the $N$. umbonifera frequency curve and the planktonic foraminiferal preservation curve suggests that the abundance of $N$. umbonifera may be an artifact of carbonate dissolution associated with the corrosive AABW.

Quantitative analyses of benthic foraminifers from the upper Neogene of Site 518 reveal three assemblages that are indicative of specific water masses in the geologic past. These include: a Nuttalides umbonifera assemblage associated with AABW; a Globocassidulina subglobosa-Uvigerina peregrina assemblage associated with neo-Circumpolar Water (neo-CPW); and an Oridorsalis umbonatus-Epistominella exigua assemblage associated with NADW. Changes in benthic foraminiferal assemblages at Site 518 are synchronous with changes in the stable isotopic and dissolution parameters (Hodell and Kennett, this volume).

\section{PALEOMAGNETICS}

A study of downhole magnetic polarity and intensity changes was pertinent to the prime objectives for this site, although at the outset a continuous magnetic polarity record was not anticipated because of the likely occurrence of hiatuses.

The sediment lithologies that were recovered at Site 518 range through nannofossil oozes in the upper part to dark brown calcareous clays in the lower part of the hole, which terminated at a depth of $72.3 \mathrm{~m}$ sub-bottom. In accordance with earlier appraisal of this technique (see site chapters, Sites 515 and 517, this volume) and because the sediments recovered here were generally firmer than at Site 517, a limited amount of whole-core spinning was attempted before the individual sections were split. Before individual cores were selected for spinning, they were carefully inspected for evidence of voids, soupy disturbance, and excessive water between liner and sediment surface. Only 18 out of a total of 45 sections were selected for whole-core spinning. Al- 
though there is therefore no continuity downhole, the whole-core declination results show evidence of declination changes that are less scattered than those observed at Site 517. Apparent reversal boundaries are detected by this method of preliminary investigation. Notably, polarity changes were recorded at 12.1, 13.6, 15.3, and $22.0 \mathrm{~m}$ sub-bottom depth, correlating with reversal boundaries within the Matuyama-upper Gauss Epochs.

A feature of the paleomagnetic investigations of 77 standard cylindrical samples taken from the split cores is the generally high natural remanent magnetization (NRM) intensity at Site 518 compared to sediments of a similar age at the other Rio Grande Rise sites (Sites 516 and 517). Mean NRM intensity measured onboard is 10.7 $\pm 8.2 \mathrm{~mA} / \mathrm{m}$. Despite a large standard deviation, NRM intensity increases markedly with increasing water depth away from the Rise crest. This trend may be related to a more abundant clay fraction at the deeper sites, because that fraction would be richer in the ultrafine-grained ferromagnetic material and less diluted by the weakly magnetic biogenous component that dominates at the shoaler levels.

Alternating field demagnetizations for the typical sediment lithologies recovered from this hole show a fairly close grouping of directions coupled with a smooth decay in intensity up to $60 \mathrm{mT}$ peak field. This behavior suggests moderate to good magnetic stability. A number of the inferred polarity reversal boundaries deduced from the whole-core spinning are confirmed by the results of the discrete sample study.

It is impossible to assign the downhole polarity changes to the established geomagnetic time scale independently of the age determinations given from the microfloral and microfaunal zonations (see Biostratigraphy section). In accordance with these determinations, the principal features of the observed magnetostratigraphy at Site 518 are as follows:

1) The Brunhes/Matuyama Epoch boundary is located at a depth of $4.0 \mathrm{~m}$ sub-bottom.

2) A split Olduvai Event is detected between 13.6 and $18.4 \mathrm{~m}$ (Cores 4 and 5). Evidently, lower Quaternary sediments at this site were deposited at a very rapid rate of about $12.0 \mathrm{~m} / \mathrm{Ma}$.

3) A change in sedimentation rate, or hiatus, may be present between the uppermost Gauss Epoch and within the basal interval of the Matuyama Epoch (i.e., below the Olduvai Event, in uppermost Pliocene).

4) The Gauss Epoch occurs between 22 and $35 \mathrm{~m}$ sub-bottom depth.

5) Only two of the Gilbert Epoch normal polarity events are detected, probably indicating a further break or change in sedimentation rate in the early Pliocene.

6) The upper part of Epoch 5 (Anomaly 3A) is identified at a sub-bottom depth of $44.5 \mathrm{~m}$.

7) Assignments below $50 \mathrm{~m}$ are questionable; parts of Epochs 12 and 15/16 may be present. The terminal 3 $\mathrm{m}$ of the hole are reversely magnetized.

\section{SEDIMENTATION RATES}

Sedimentation rates at Site 518 are based on planktonic foraminiferal and calcareous nannoplankton stra- tigraphy and magnetic reversals, combined by means of the Neogene time scale of Berggren, Kent, and Van Couvering (in press). Stratigraphic control is not uniformly good down the section. Preservation is poor and both Quaternary and Miocene sediments contain reworked older fossils. This combination of reworking and dissolution may explain the discrepancies apparent in Figure 4 between nannofossil and foraminiferal ages. Because of incomplete recovery and core disturbance the magnetic measurements are not continuous, so the magnetic reversal identifications are not fully independent of the biostratigraphy.

Because of the imperfect stratigraphic control, the age-depth curve in Figure 4 is not unique. In particular, the hiatus at about $44 \mathrm{~m}$ may not exist if planktonic foraminiferal ages are preferred, and other hiatuses may occur between 54 and $59 \mathrm{~m}$ and between 59 and $62 \mathrm{~m}$ if the nannofossil ages are preferred. Sedimentation rates average $8 \mathrm{~m} / \mathrm{Ma}$ through the Pleistocene and $12 \mathrm{~m} / \mathrm{Ma}$ through most of the Pliocene. Many combinations of sedimentation rates and hiatuses may be invoked for the Miocene.

\section{CORRELATION OF REFLECTION PROFILER DATA WITH DRILLING RESULTS}

HPC coring at Site 518 penetrated only $72.3 \mathrm{~m}$ of Recent to lower Miocene sediment. According to compressional-wave velocities measured on the cores (see Sedimentation Rates section), this amounts to only $0.094 \mathrm{~s}$. The only possible source of a seismic reflector is the downhole change from foraminiferal-nannofossil ooze to terrigenous mud at about $55 \mathrm{~m}(0.07 \mathrm{~s})$.

The University of Texas Marine Science Institute (UTMSI) Profile WSA8 across the site (Fig. 5) shows a hummocky structure in midsection, better developed downslope on the Vema Terrace. Beneath this feature, at about $0.8 \mathrm{~s}$ at Site 518 , lies a reflector that we associate speculatively with the Eocene/Oligocene boundary hiatus cored at Site 515. Above, and becoming better defined upslope, the acoustic character suggests pelagic deposition, perhaps of calcareous sediment. As the drilling results and the $3.5-\mathrm{kHz}$ record (Fig. 6) at the site suggest, however, this interpretation is oversimplified. On a small scale, the shallow topography is also hummocky; a reflector that may correspond to the ooze/clay transition is just about visible, but is not continuous. Thus, a conventional reflection profile may reflect a dominant lithology, but it does not show the small-scale changes that occur in the cored section.

\section{SUMMARY AND CONCLUSIONS}

Site 518 is located near the break in slope between the Vema Channel Terrace and the west flank of the Rio Grande Rise, in a water depth of $3944 \mathrm{~m}$. This depth is near the base of the transition between AABW and NADW on the eastern margin of the Channel. The primary objective of coring at the site was to extend into the Neogene the previous interpretations of Pleistocene fluctuations of the AABW/NADW transition zone, and to integrate these results with the evidence from Site 515 regarding Neogene pulses of AABW. 


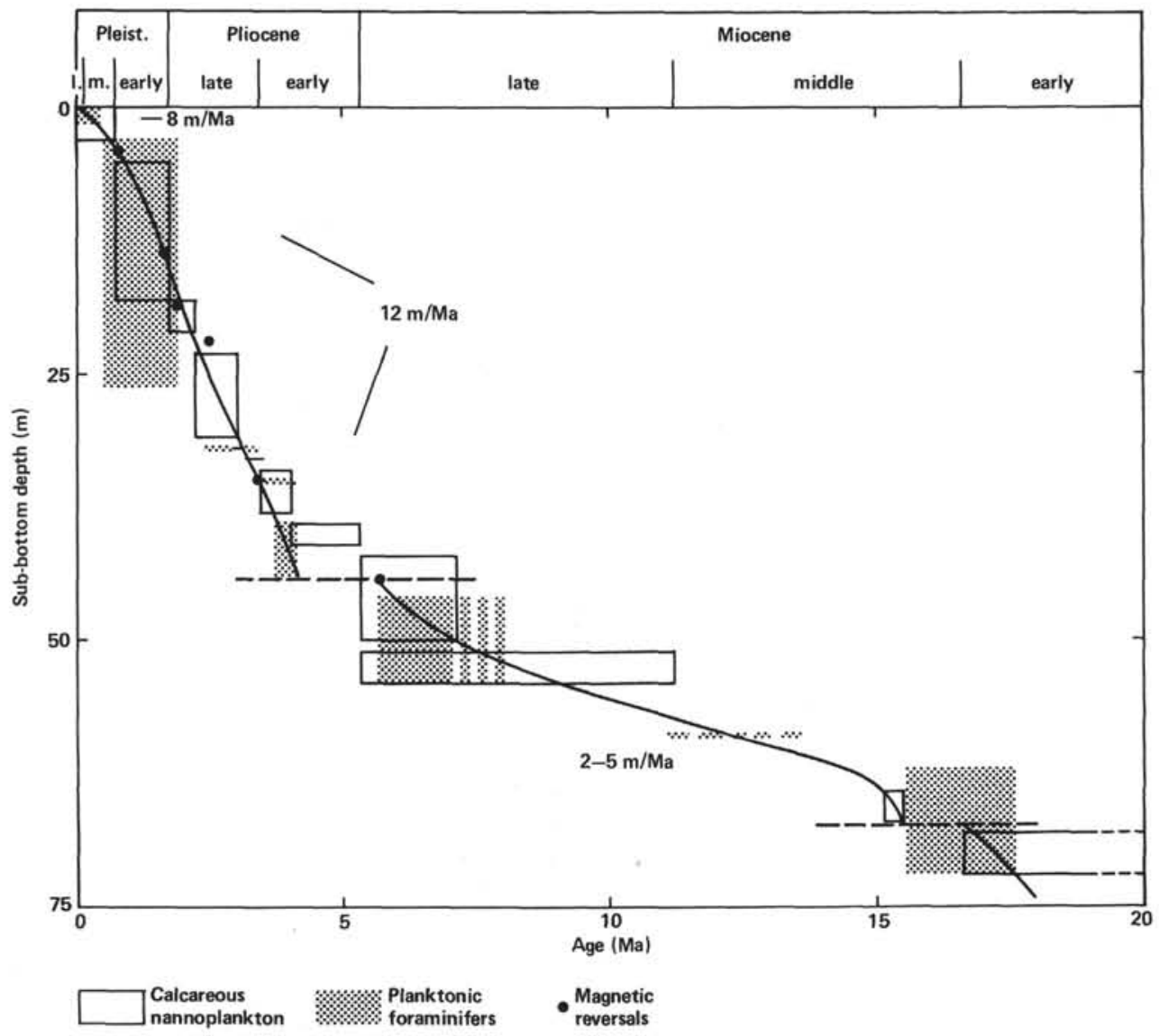

Figure 4. Sedimentation rates, Site 518.

The site consisted of a single HPC hole, with the deepest sediment recovered from $71.94 \mathrm{~m}$ sub-bottom in Core 18 (Core 19 was empty). The oldest sediment recovered was early Miocene (Zones NN4/5 and N6; approximately $18-19 \mathrm{Ma}$ ).

Two principal lithologic units were recognized. The uppermost consists of foraminiferal-nannofossil oozes, with occasional foraminiferal sand layers (turbidites?), and extensive reworking in Cores 5 to 7 . Terrigenous muds and marly nannofossil oozes compose the remaining $17.9 \mathrm{~m}$, with minor amounts of zeolites, detrital mineral grains, and volcanic glass.

At least four significant stratigraphic gaps interrupt the continuity of the sequence cored at Site 518. From youngest to oldest, they are as follows:

1) At the upper Pliocene/lower Pleistocene boundary, Zones NN17/18 to PL5/6 may be condensed or missing entirely.

2) At the Pliocene/Miocene boundary, Zones PL1a/ PL1b and NN12/13 may be condensed or missing.

3) The upper Miocene may be largely missing: Zones NN9 (part), NN10, and NN11 (part).

4) Part of the middle Miocene may be missing (Zones NN5 to 7; N14 to 16).

Some of these unconformities, particularly the missing upper Miocene, may be equivalent in age to those observed at Sites 357 and 516 near the crest of the Rise; therefore, the hiatuses at Site 518 are not necessarily a consequence of deep water mass movements.
Changes in the benthic foraminiferal assemblages, stable isotopes, and dissolution indices at Site 518 monitor changes in the production of AABW and NADW (Hodell and Kennett, this volume). The production of these water masses appears to have covaried during the late Neogene. Times of increased bottom water production are marked by (1) dominance of both the $N$. umbonifera and the $O$. umbonatus-E. exigua assemblages; (2) an increase in the vertical $\delta^{13} \mathrm{C}$ gradient between Holes 516A and 518 such that $\delta^{13} \mathrm{C}$ values significantly lighten at the deeper site (518) (Hodell and Kennett, this volume); and (3) an increase in carbonate dissolution (Hodell and Kennett, this volume). These conditions prevailed in the late Neogene between 3.6 and $4.0 \mathrm{Ma}$, and between 2.7 and 3.2 Ma. Increased AABW and NADW production at these times are related to rapid climatic deterioration associated with the terminal Miocene and late Pliocene paleoceanographic events (Hodell and Kennett, this volume). A hiatus spans the Miocene/Pliocene boundary at Site 518 from 4.0 to $5.5 \mathrm{Ma}$; it may have resulted from the intensification of abyssal circulation. Intensification of bottom water production at $3.0 \mathrm{Ma}$ is coincident with a $1.0 \%{ }_{0} \delta^{18} \mathrm{O}$ enrichment in benthic foraminiferal tests (Hodell and Kennett, this volume), heralding the initial development of ice on northern hemisphere continents.

Bottom water production diminished during the Messinian of the latest Miocene (about 5.5-6.0 Ma) and during the middle Pliocene (3.2 to $3.6 \mathrm{Ma}$ ) (Hodell and 


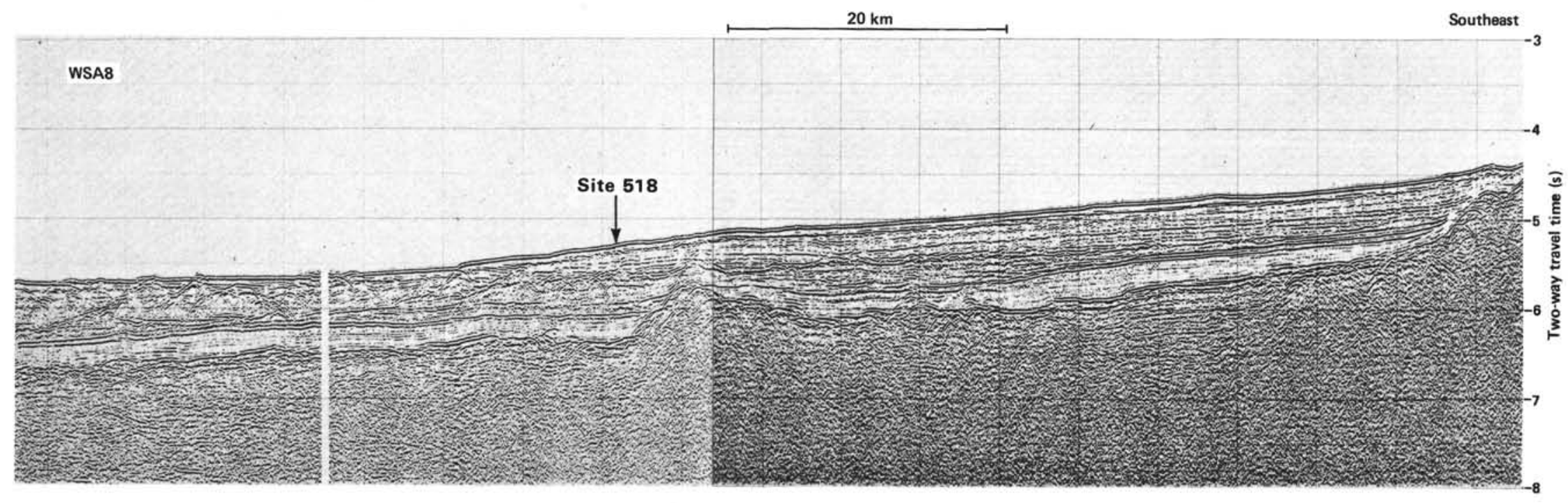

Figure 5. Multichannel seismic reflection profile (UTMSI-WSA8) through Site 518. 


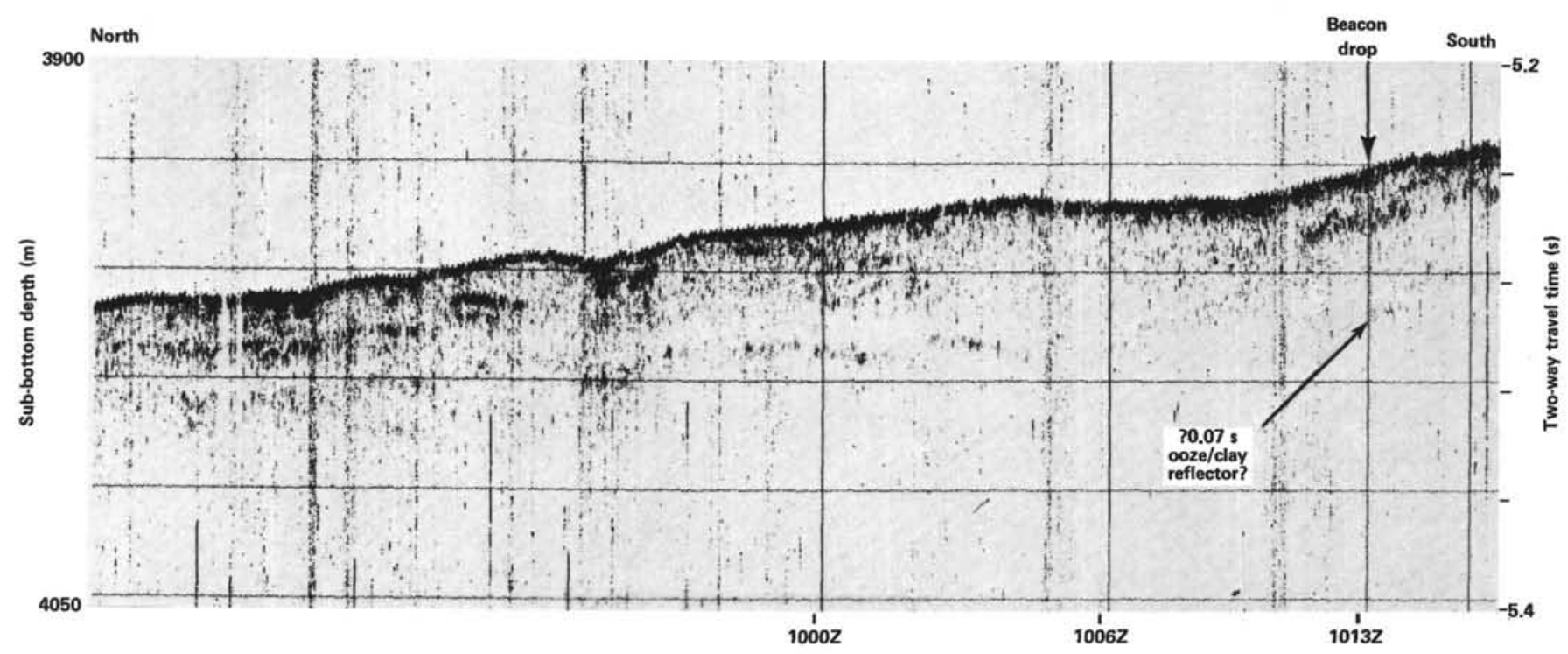

Figure 6. Glomar Challenger $3.5-\mathrm{kHz}$ profile near Site 518 .

Kennett, this volume). Those times are marked by (1) a G. subglobosa-U. peregrina assemblage at Site 518, (2) the lack of a $\delta^{13} \mathrm{C}$ gradient between Holes 516A and 518, and (3) increases in faunal preservation. Youthful, neoCPW probably expanded to depths of at least $3944 \mathrm{~m}$ during these time intervals. The youth of neo-CPW may reflect a decreased residence time caused by the intensification of the Antarctic Circumpolar Current.

A complete bathymetric $\delta^{13} \mathrm{C}$ profile between surface (about $50 \mathrm{~m}$, planktonic foraminifers), intermediate (1313 m, Hole 516A), deep (2963 m, Site 517), and bottom waters (3944 m, Site 518 ) is available for the upper Pliocene. A comparison of present-day vertical $\delta^{13} \mathrm{C}$ structure of the water column in the Vema Channel to a $\delta^{13} \mathrm{C}$ reconstruction of the structure between 2.7 and 3.2 $\mathrm{Ma}$ indicates that the modern circulation patterns of the western South Atlantic had been established by $3.2 \mathrm{Ma}$.

\section{REFERENCES}

Berggren, W. A., 1977a. Late Neogene planktonic foraminiferal biostratigraphy of the Rio Grande Rise (South Atlantic). Mar. Micropaleontol., 2:265-313.

, 1977b. Late Neogene planktonic foraminiferal biostratigraphy of DSDP Site 357 (Rio Grande Rise). In Supko, P. R., Perch-Nielsen, K. P., et al., Init. Repts. DSDP, 39: Washington (U.S. Govt. Printing Office), 591-614.

Berggren, W. A., Kent, D. V., and Van Couvering, J. A., in press. Neogene geochronology and chronostratigraphy. In Snelling, N. J. (Ed.), Geochronology and the Geologic Record: London (Geol. Soc. London Spec. Publ.).

Blow, W. H., 1969. Late middle Eocene to Recent planktonic foraminiferal biostratigraphy. In Brönnimann, P., and Renz, H. H. (Eds.), Proc. First. Int. Conf. Plankt. Microfossils: Leiden (E. J. Brill), 1:199-422.
Ciesielski, P. F., Ledbetter, M. T., and Ellwood, B. B., 1982. The development of Antarctic glaciation and the Neogene paleoenvironment of the Maurice Ewing Bank. Mar. Geol., 46:1-51.

Ellwood, B. B., and Ledbetter, M. T., 1977. Antarctic Bottom Water fluctuations in the Vema Channel: effects of velocity changes on particle alignment and size. Earth Planet. Sci. Lett., 35:189-198.

Haq, B., and Berggren, W., 1978. Late Neogene calcareous plankton biochronology of the Rio Grande Rise (South Atlantic Ocean). J. Paleontol., 52:1167-1194.

Hogg, N. G., Biscaye, P., Gardner, W., and Schmitz, W. J., 1982. On the transport and modification of Antarctic Bottom Water in the Vema Channel. J. Mar. Res., 40(suppl.):231-263.

Johnson, D. A., Ledbetter, M., and Burckle, L. H., 1977. Vema Channel paleoceanography: Pleistocene dissolution cycles and episodic bottom water flow. Mar. Geol., 23:1-33.

Johnson, D. A., McDowell, S. E., Sullivan, L. G., and Biscaye, P. E., 1976. Abyssal hydrography, nephelometry, currents, and benthic boundary layer structure in the Vema Channel. J. Geophys. Res., 81:5771-5786.

Ledbetter, M. T., 1979. Fluctuations of Antarctic Bottom Water velocity in the Vema Channel during the last 160,000 years. Mar. Geol., 33:71-89.

Lohmann, G. P., 1978. Abyssal benthonic foraminifera as hydrographic indicators in the western South Atlantic Ocean. J. Foraminiferal Res., 8:6-34.

Martini, E., 1971. Standard Tertiary and Quaternary calcareous nannoplankton zonation. In Farinacci, A. (Ed.), Proc. II Plankt. Conf. Roma: Rome (Edizioni Tecnoscienza), 2:739-785.

Van Couvering, J. A., and Berggren, W. A., 1977. The biostratigraphic basis of the Neogene time scale. In Hazel, J. E., and Kauffman, E., Concepts and Methods of Biostratigraphy: Stroudsberg, PA (Dowden, Hutchenson and Ross), pp. 283-306.

Williams, D. F., and Ledbetter, M. T., 1979. Chronology of late Brunhes biostratigraphy and late Cenozoic disconformities in the Vema Channel (South Atlantic). Mar. Micropaleontol., 4:125-136.

Date of Initial Receipt: November 22, 1982 


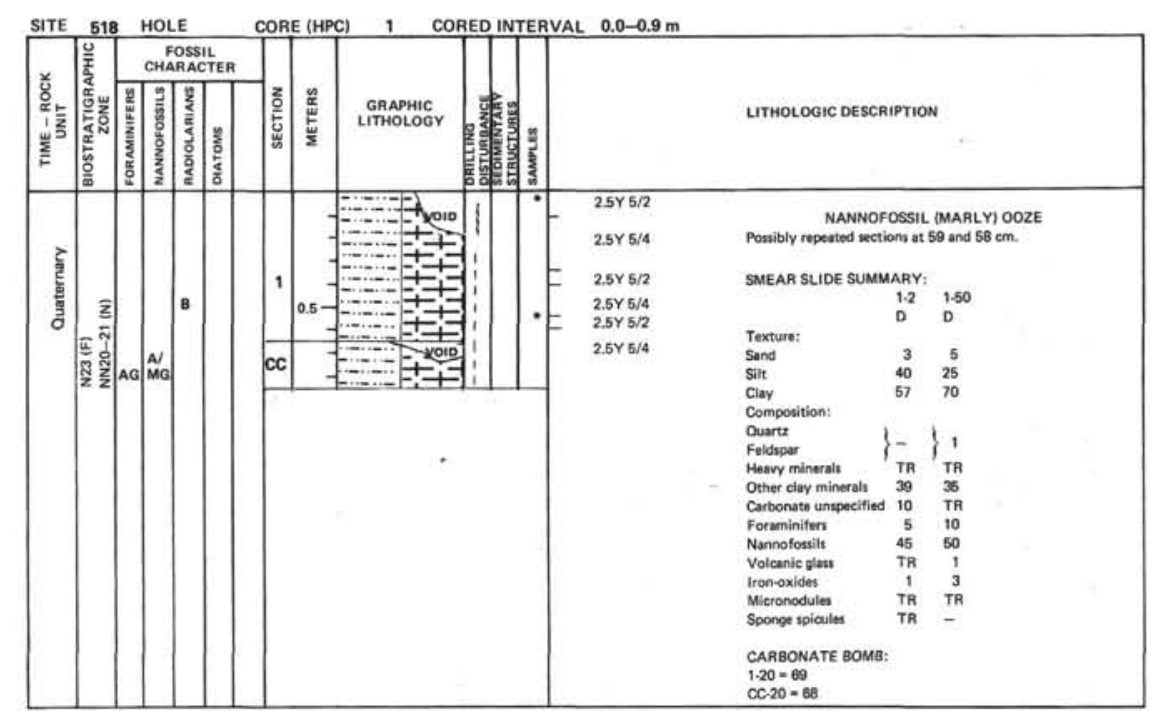

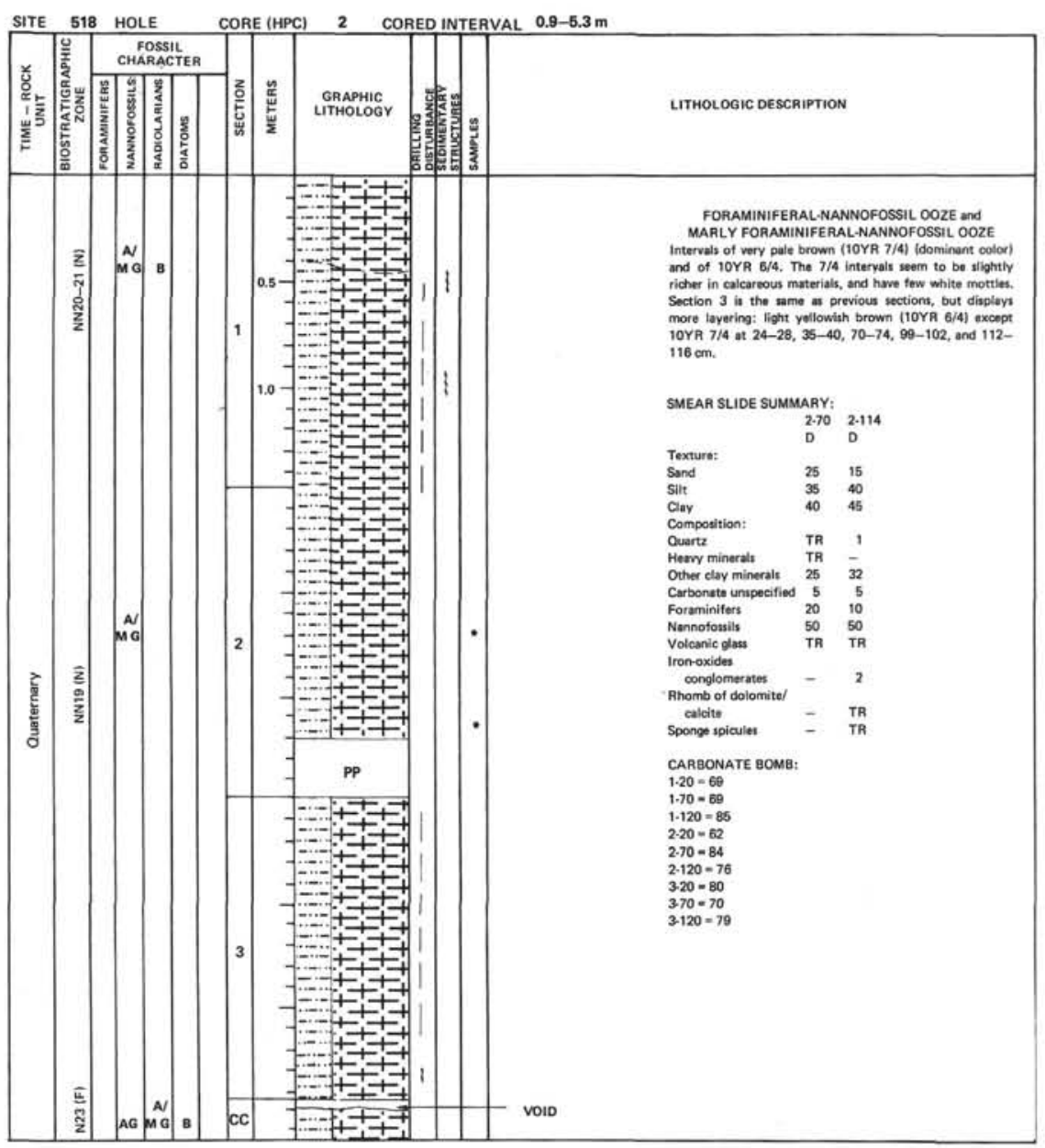




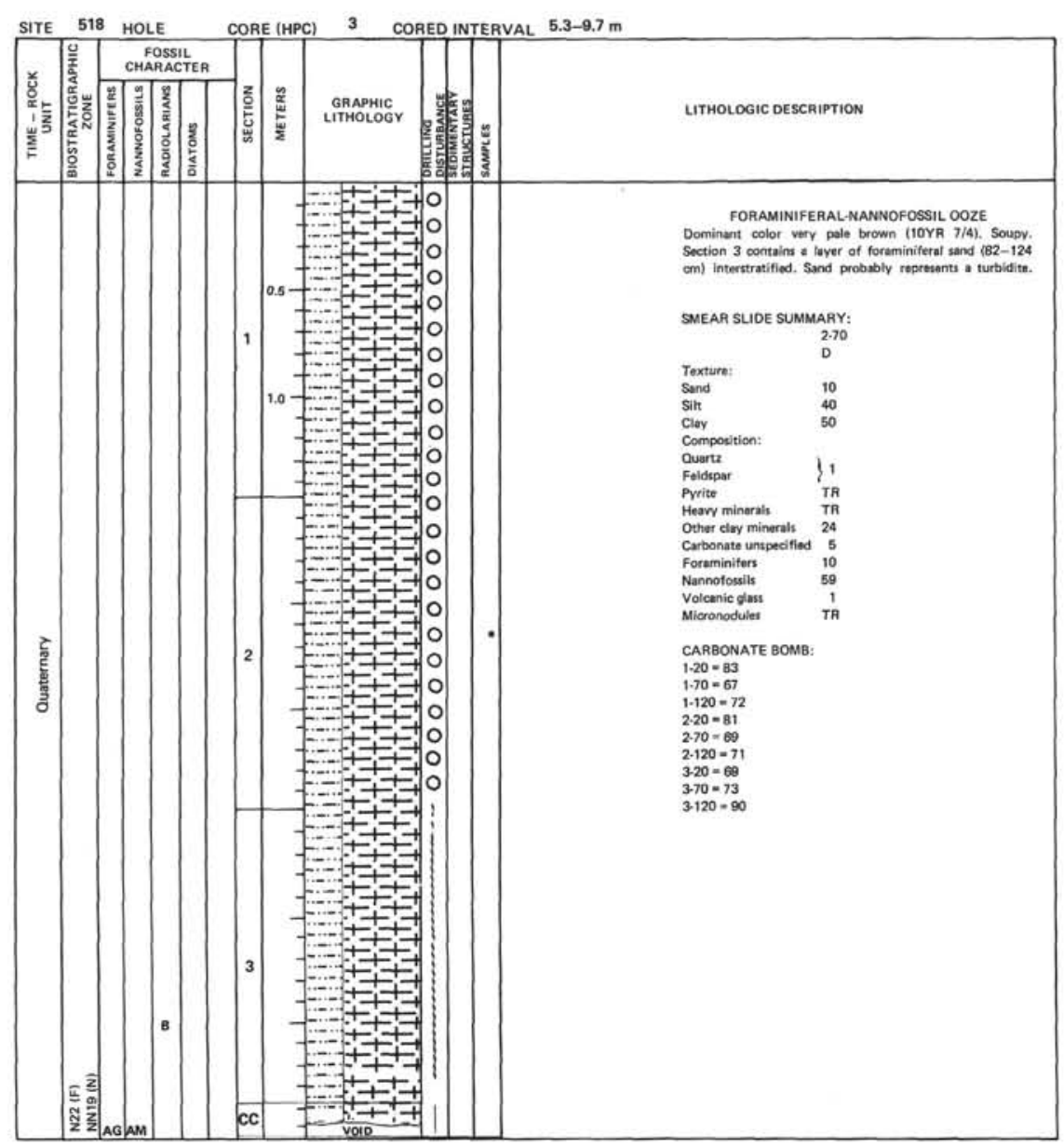

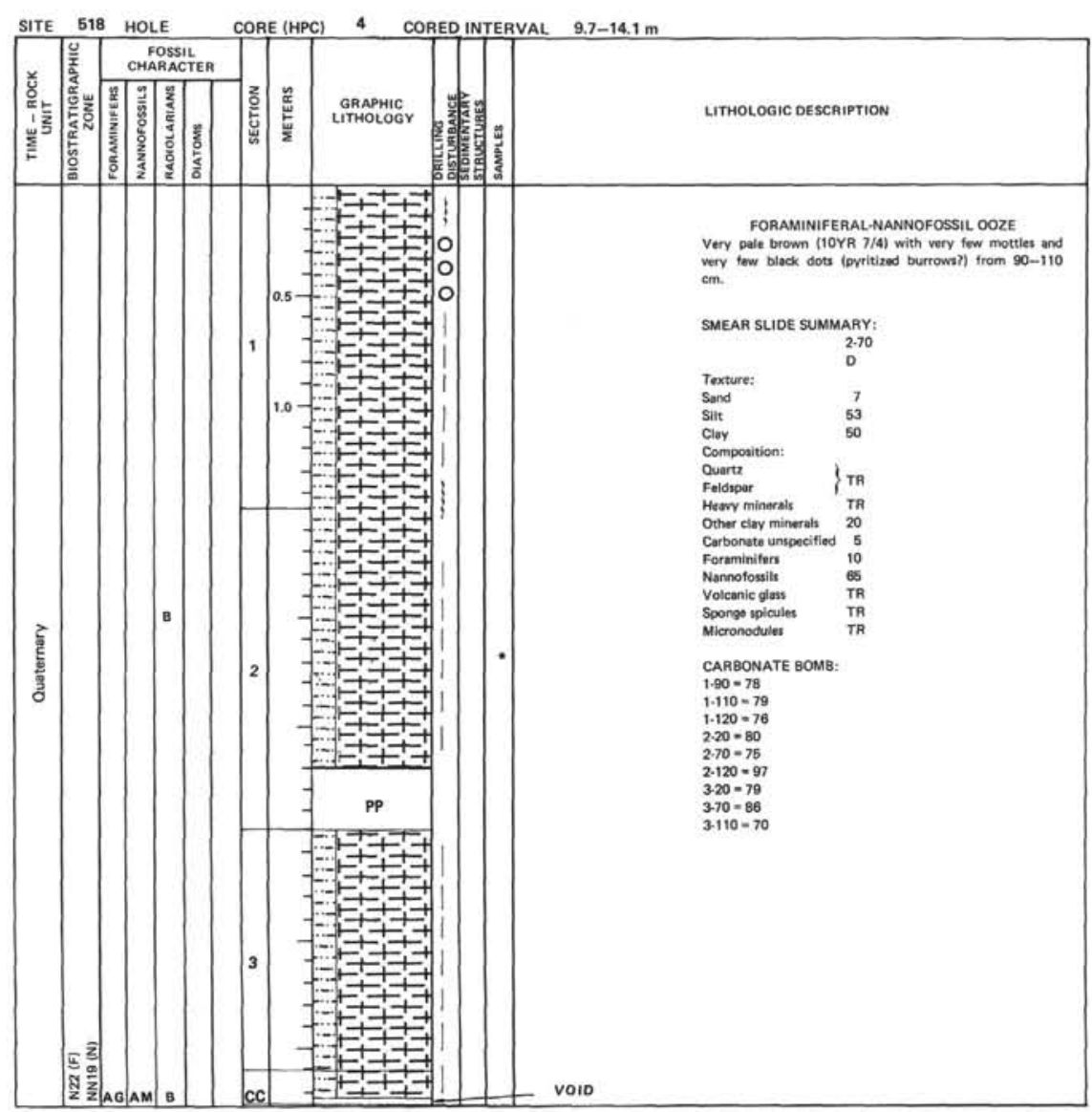



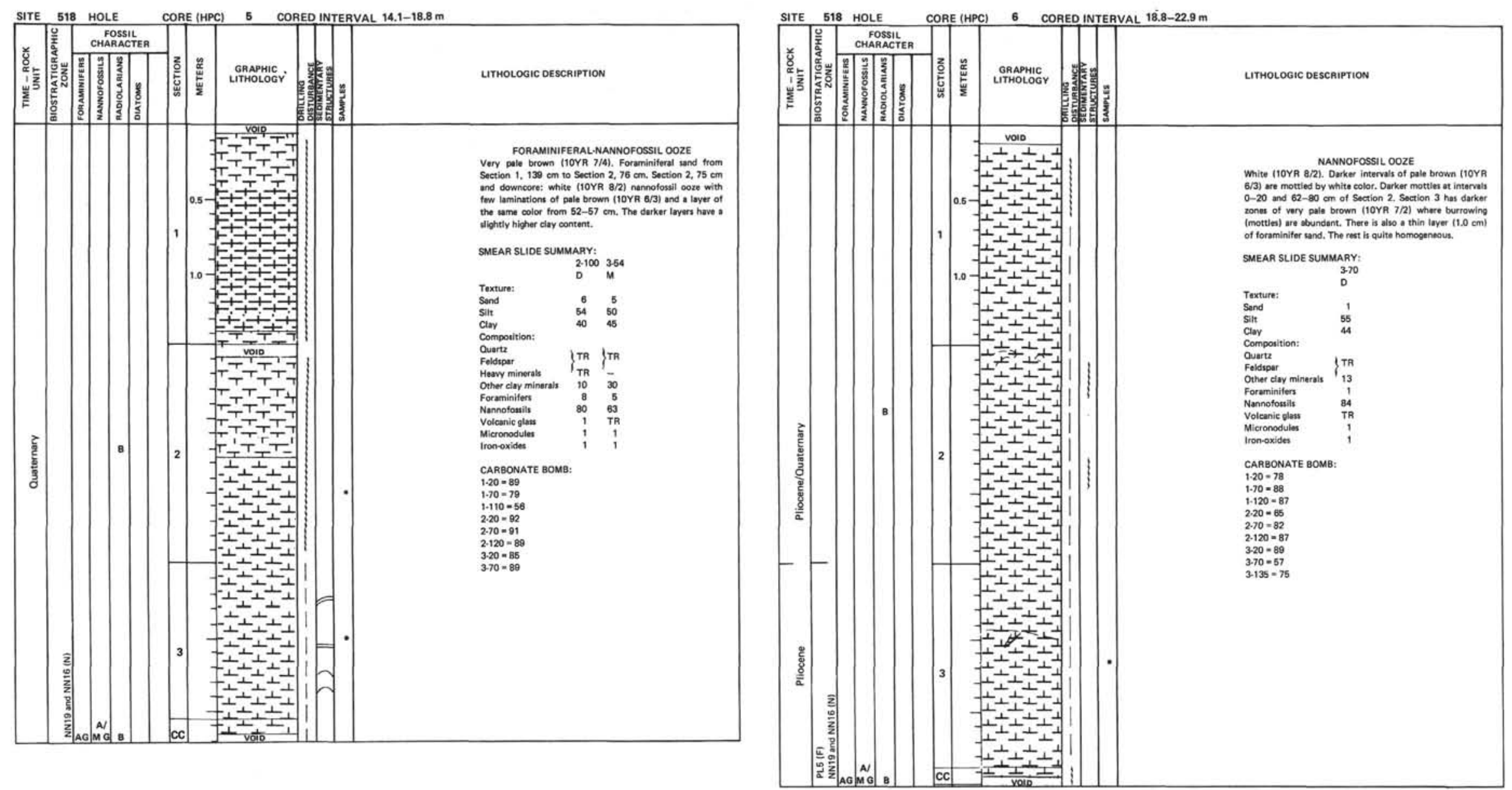


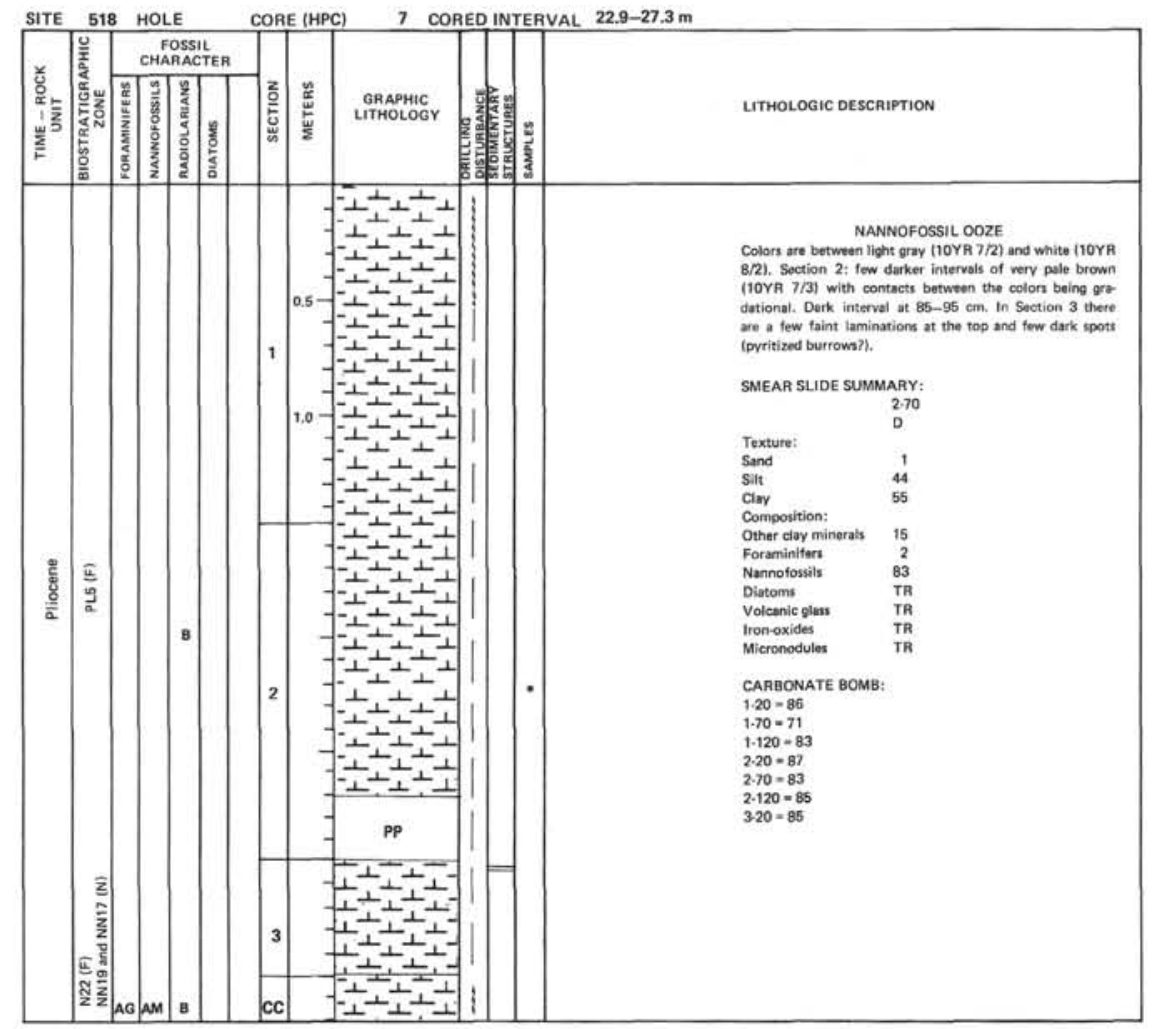

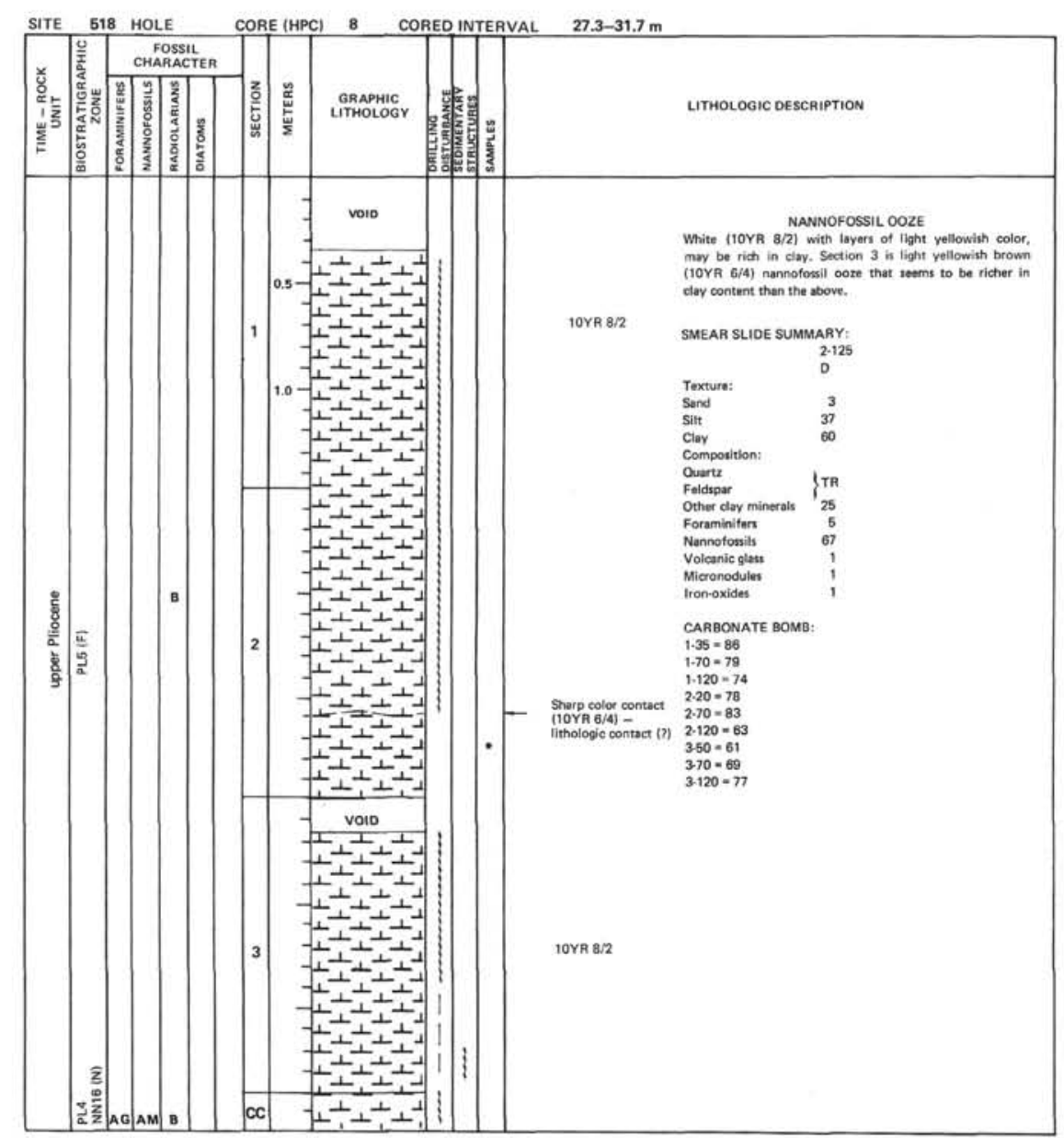




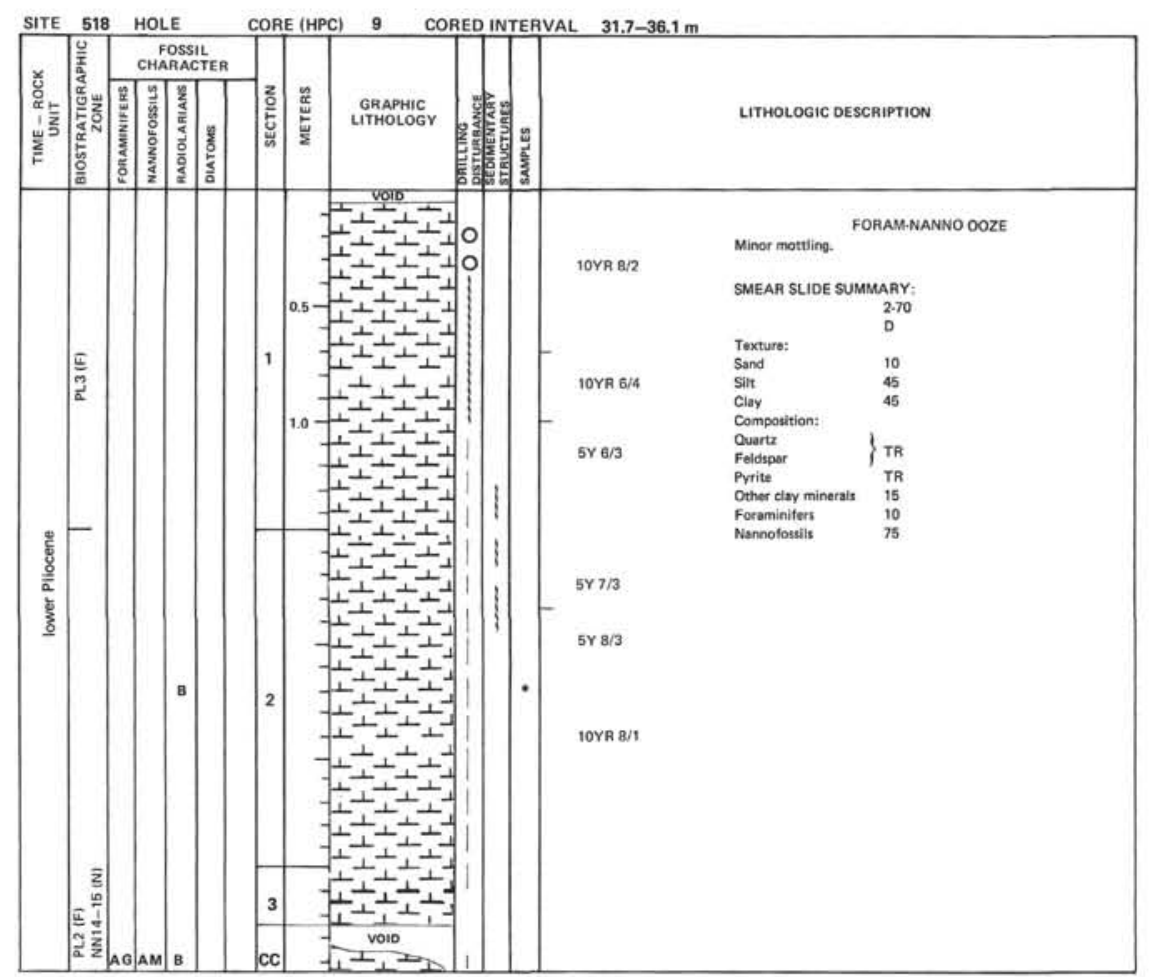

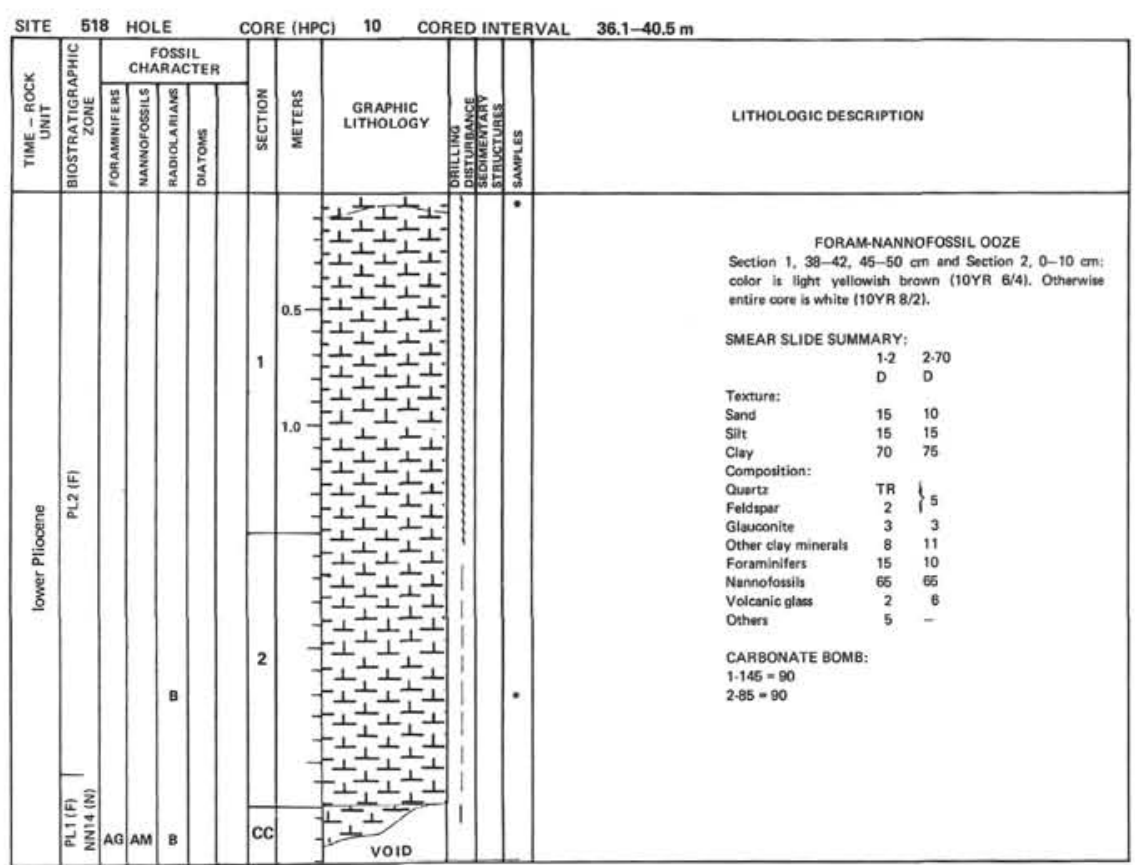



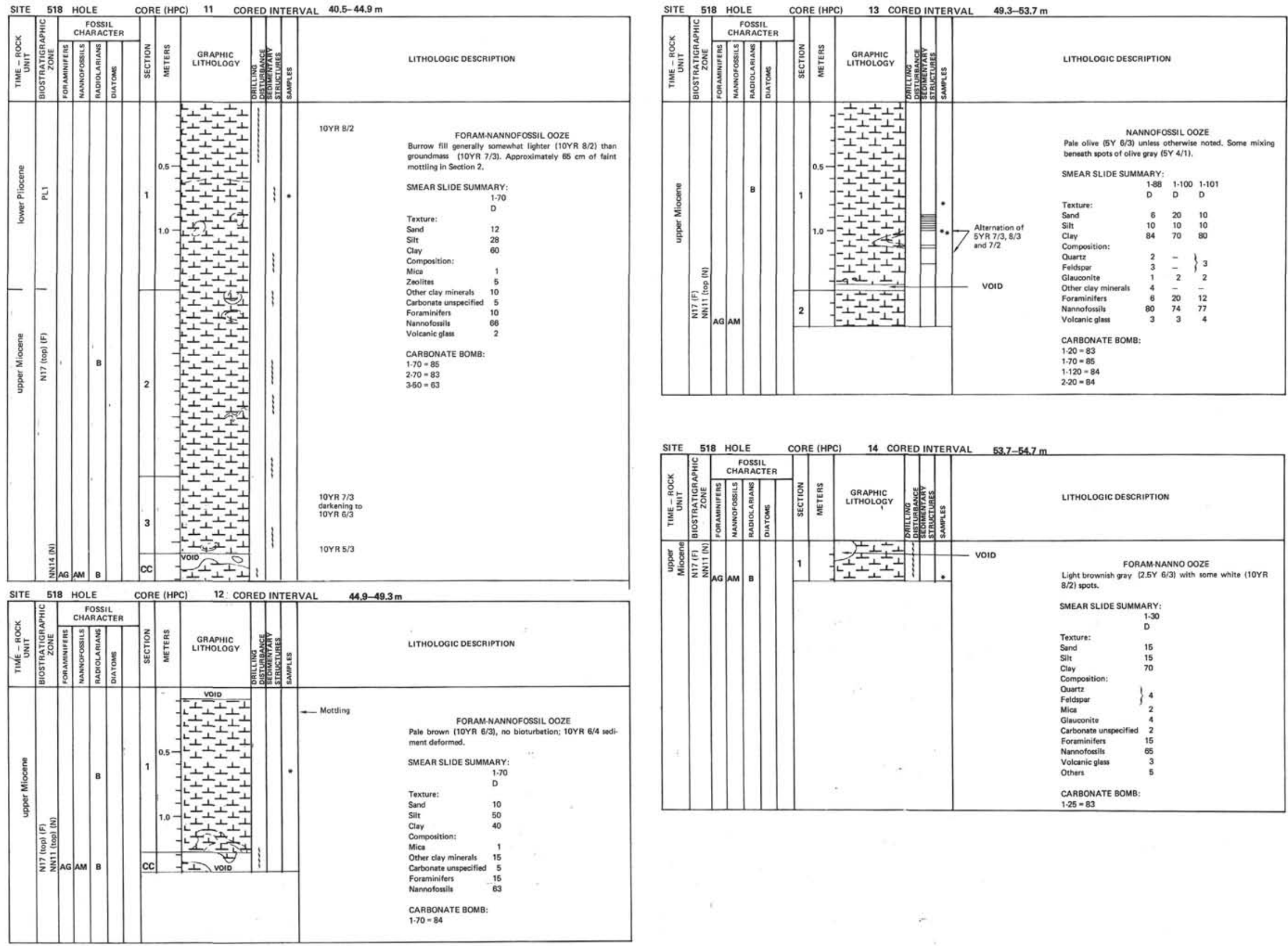

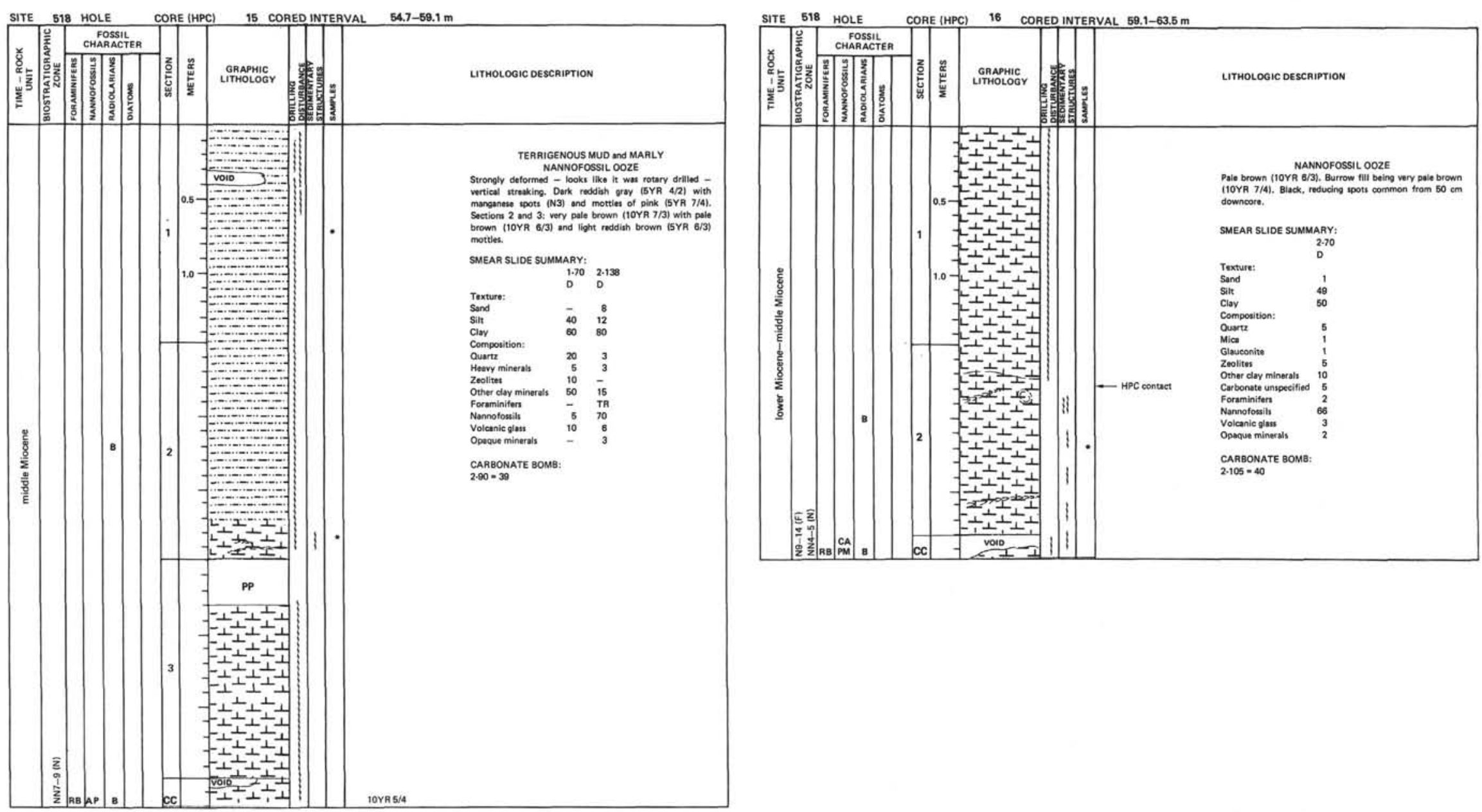


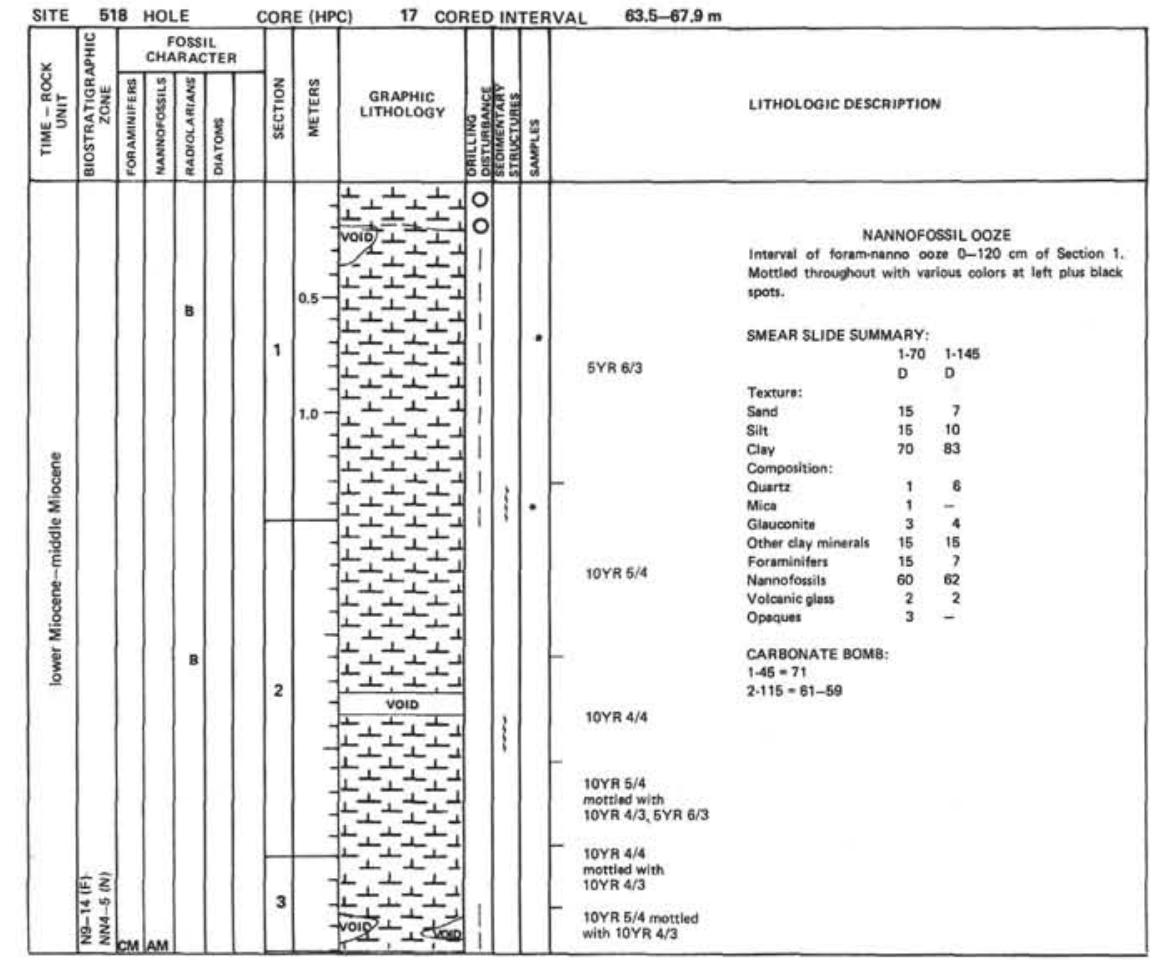

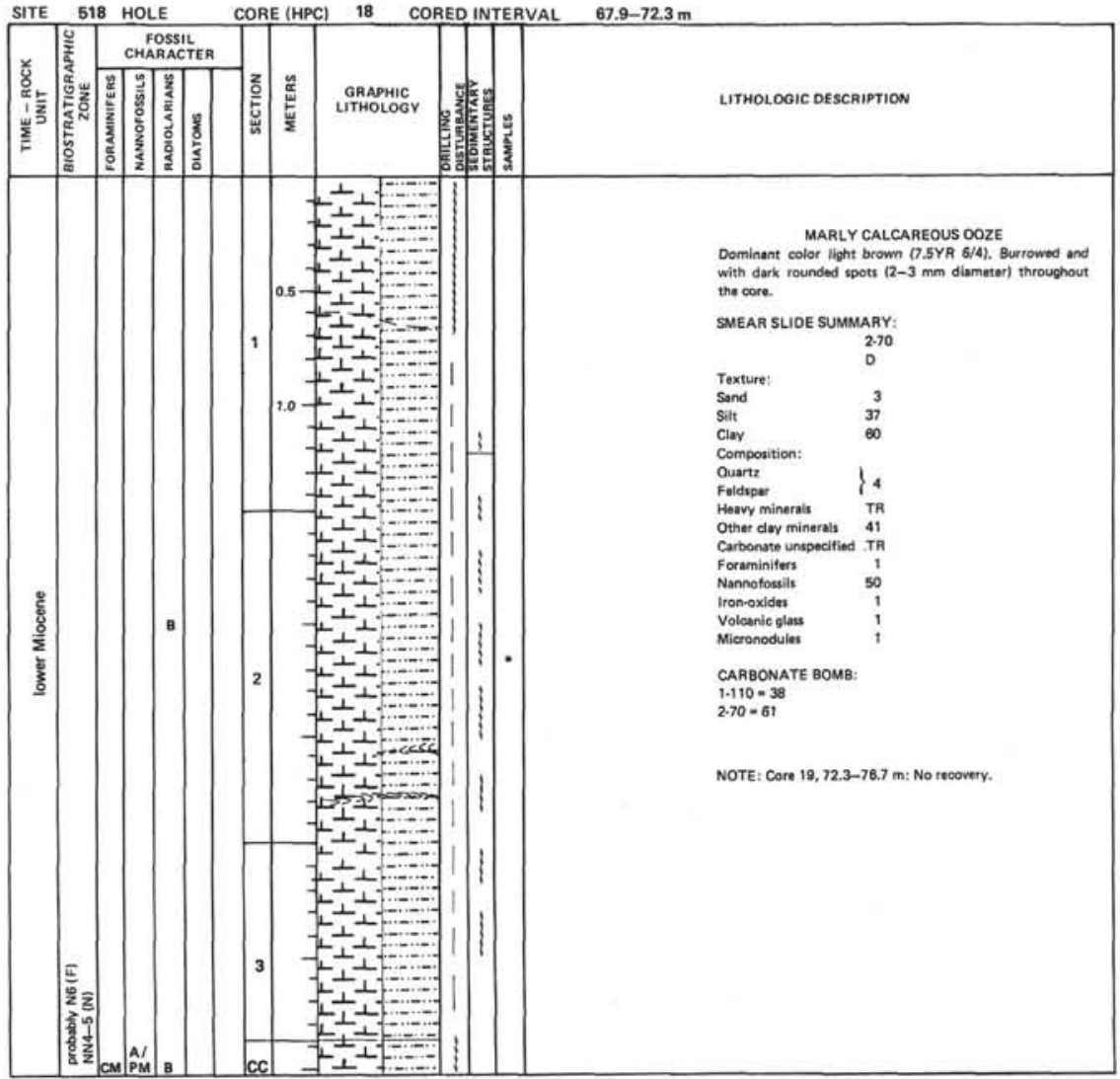




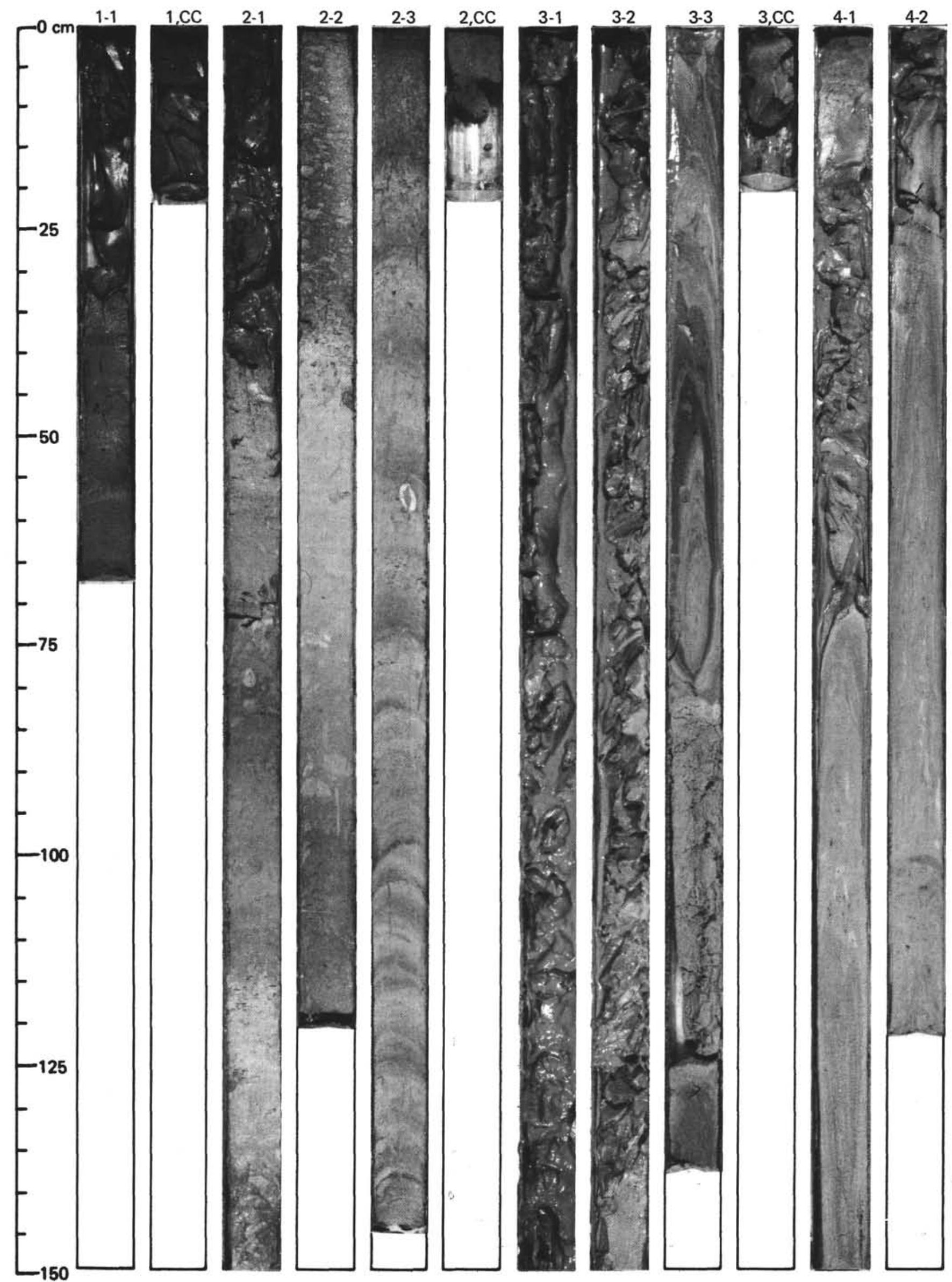


SITE 518 (HOLE 518)

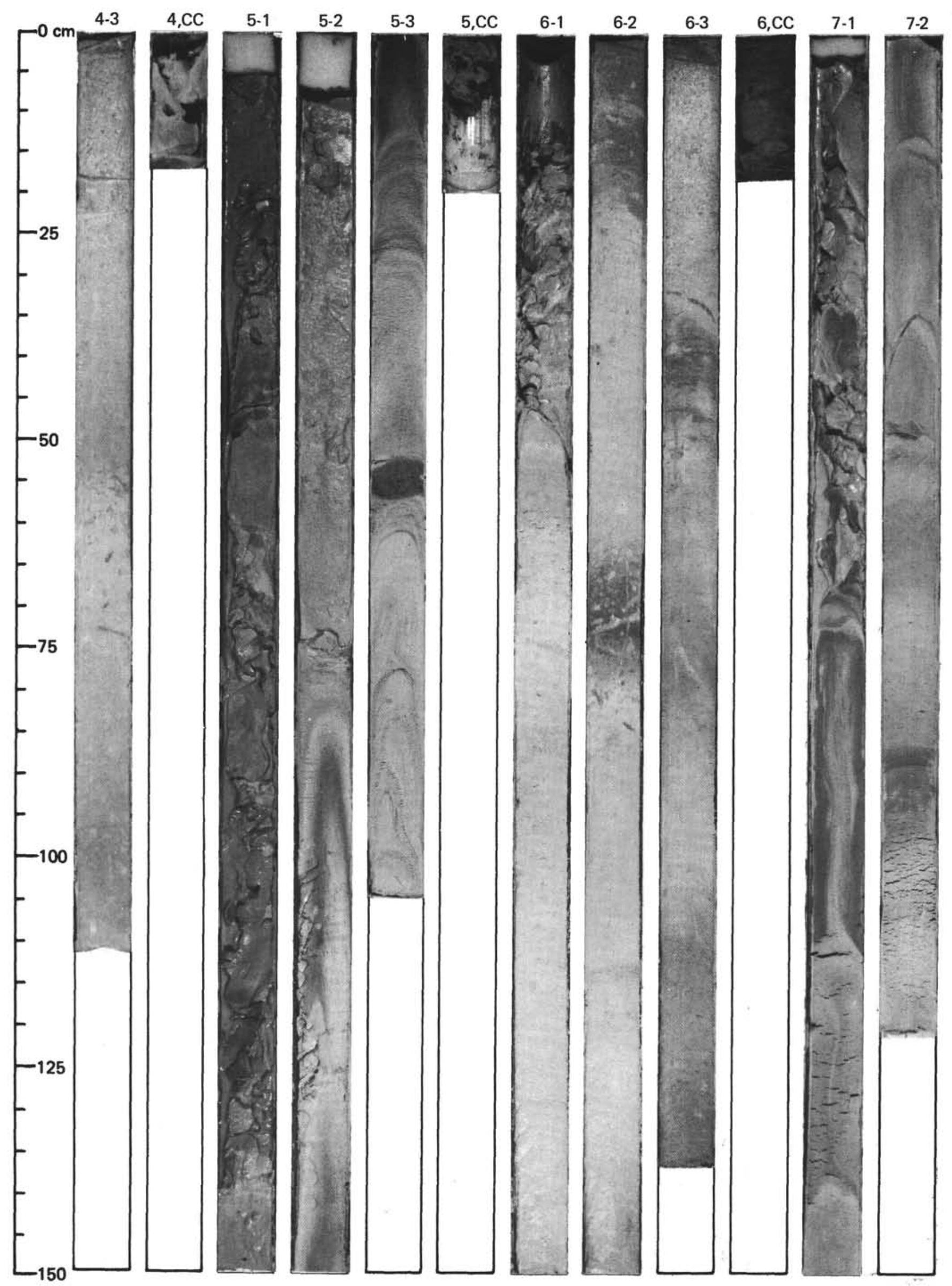




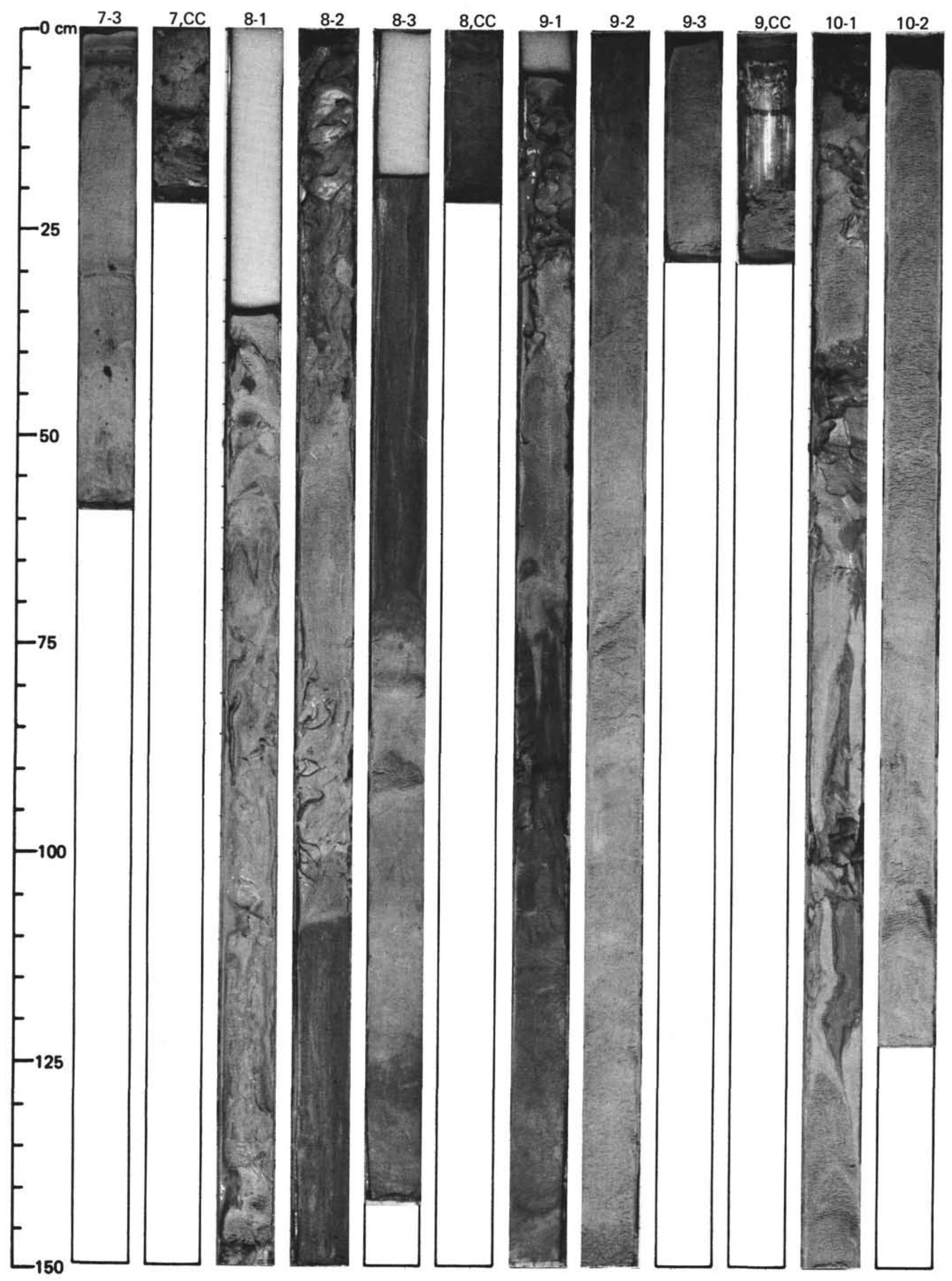


SITE 518 (HOLE 518)

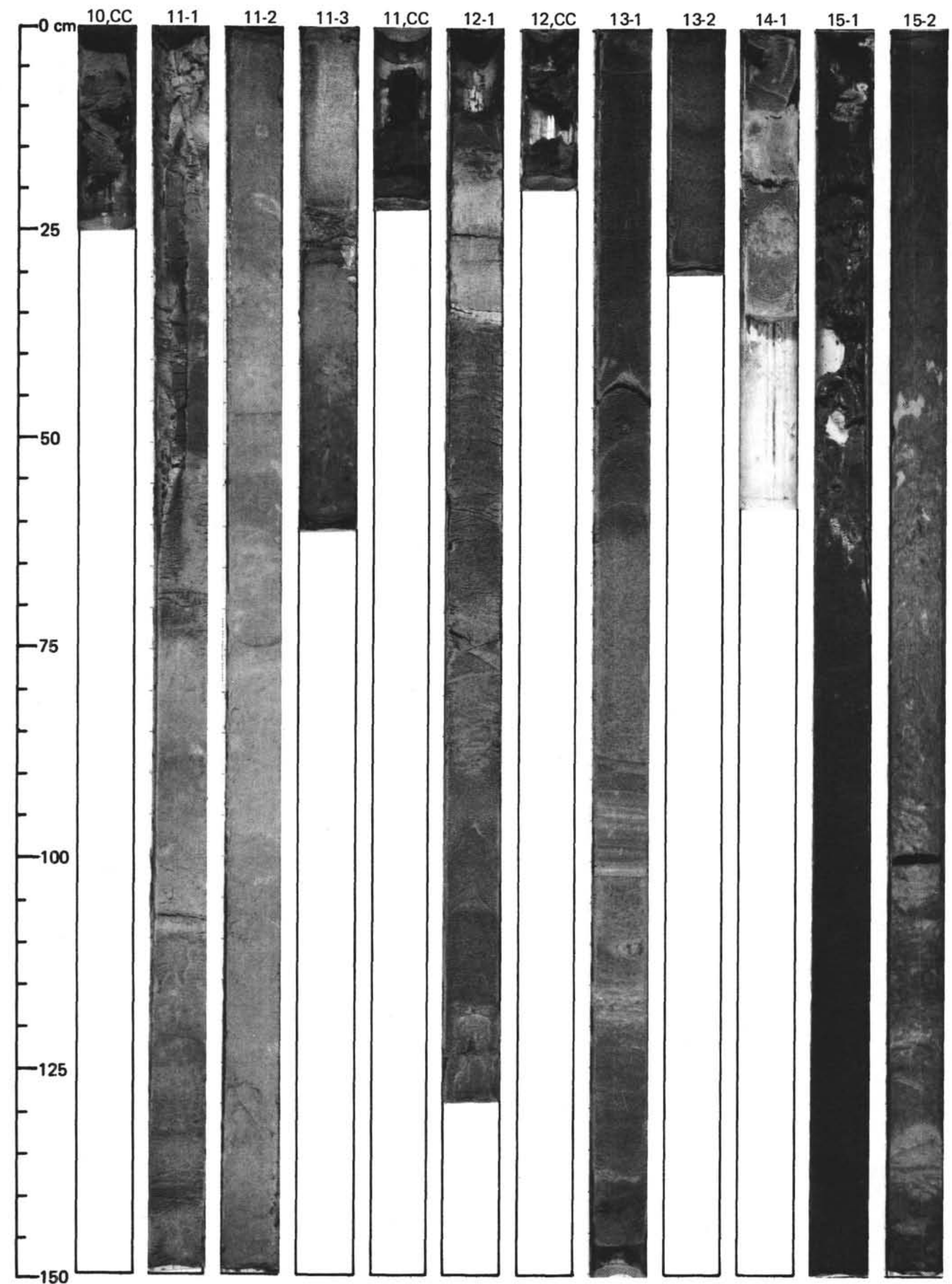




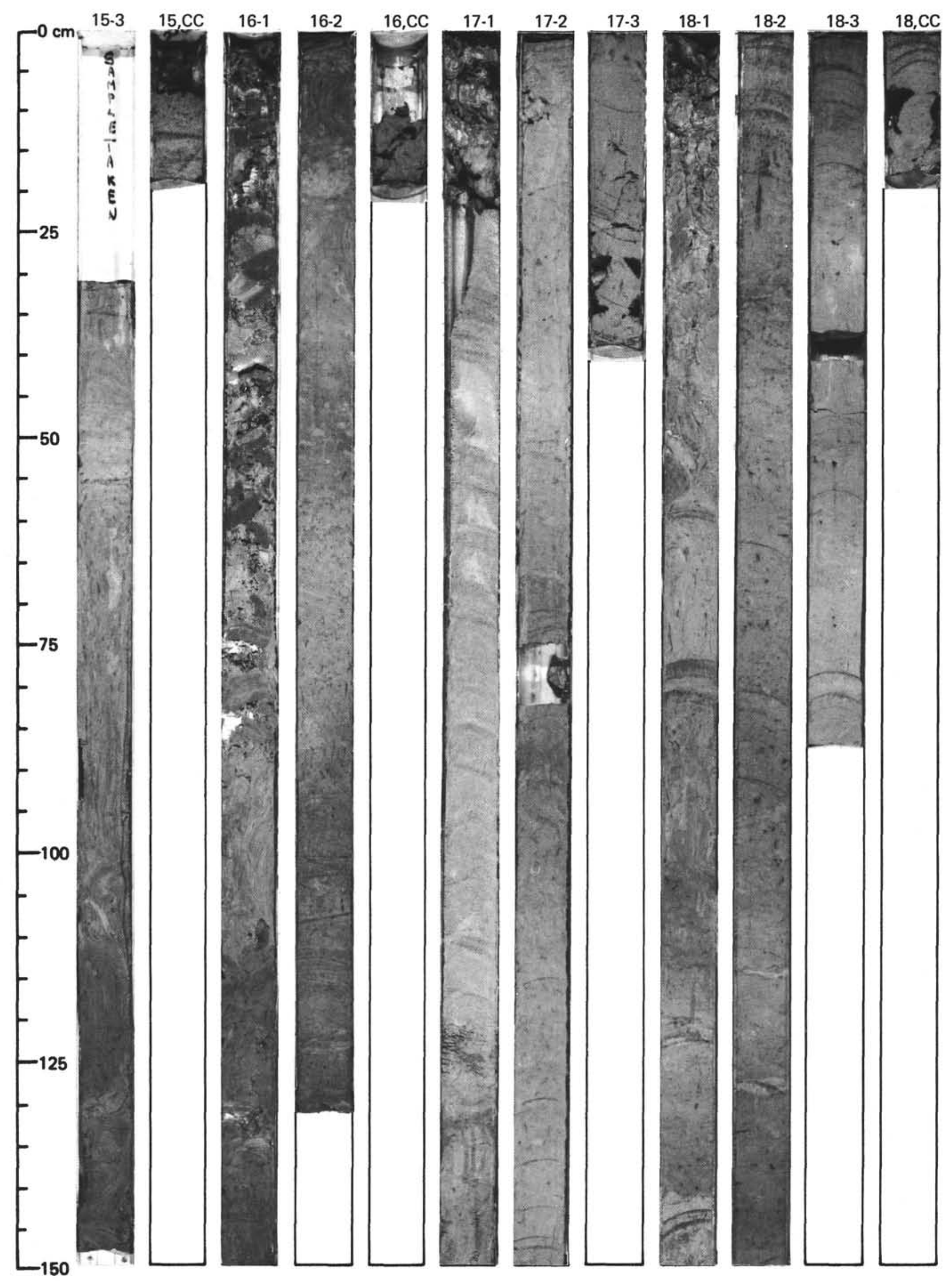

